\title{
Contaminant Exchange rates in estuaries - new formulae accounting for advection and
}

\section{dispersion}

\author{
Fernando P. Andutta ${ }^{1,2}$, Peter V. Ridd ${ }^{1}$, Eric Deleersnijder ${ }^{3,4}$, David Prandle $^{5}$
}

${ }^{1}$ School of Engineering and Physical sciences, James Cook University, Townsville QLD 4811, Australia.

${ }^{2}$ School of Physical, Environmental and Mathematical Sciences, University of New South Wales at Australian Defence Force Academy UNSW-ADFA, ACT 2600, Australia.

${ }^{3}$ Université catholique de Louvain (UCL), Institute of Mechanics, Materials and Civil Engineering (IMMC), 4 Avenue Georges Lemaître, Bte L4.05.02, B-1348 Louvain-la-Neuve, Belgium

${ }^{4}$ Université catholique de Louvain (UCL), Earth and Life Institute (ELI), Georges Lemaître Centre for Earth and Climate Research (TECLIM), 3 Place Louis Pasteur, Bte L4.03.08, B-1348 Louvain-la-Neuve, Belgium

5 National Oceanography Centre, Joseph Proudman Building, 6 Brownlow Street, Liverpool L3 5DA, UK.

* Corresponding author. Email: fernando.andutta@my.jcu.edu.au; f.andutta@adfa.edu.au; andutta@usp.br

Abstract - The transport timescales of water in an estuary are important measurements for monitoring pollution threats to the estuarine ecosystem. In this study we re-evaluated the application of simple analytical solutions to estimate these timescales and found that the Land Ocean Interaction Costal Zone model (LOICZ) uses similar equation as from the Fresh Water Fraction model, and thus often resulting in shortened transport timescales. Therefore, the LOICZ model is neither based upon the well-known Knudsen relation nor Fischer formulation. Three transport timescales, namely water renewal, residence time and exposure time were calculated using analytical solutions for a range of estuaries worldwide. The analytical results were compared with available estimates of residence times from numerical models. The theoretical formulation from the LOICZ, the fresh water fraction model, and a newly proposed modified LOICZ model were used to calculate water renewal. Residence times and exposure times were calculated using the Constituentoriented Age and Residence time Theory (CART). The modified LOICZ model was found to be the most comparable to residence times from numerical models, with $r^{2} \sim 0.7$. In addition to the proposed modified LOICZ model (which uses Fischer formulation), we have developed an 
advection-dispersion timescale diagram. This graphic conceptual model provides a visual representation of the relative contribution of advective and dispersive processes to water renewal for different estuaries. Estuaries can be categorized as either dominated by dispersion, dominated by advection, or having dispersion and advection of similar magnitude.

Keywords: LOICZ model; CART model; Fresh water fraction model; water renewal, residence time; exposure time; return coefficient.

\section{Introduction}

The transport timescales of water in an estuary are important measurements to analyse and estimate pollution threats to the estuarine ecosystem (Lucas et al., 2009; McLusky and Elliott, 2004; Wolanski, 2007). There are a number of defined transport timescales, namely (1) the flushing time, (2) the age, (3) the residence time, (4) the exposure time, and (5) the renewal time. The flushing time is defined as the time taken for a concentration to decrease to $1 / \mathrm{e}(\sim 0.37)$ of its initial value, i.e. the time necessary for $\sim 63 \%$ of a concentration (e.g. passive tracer particles) to cross the open boundary of an aquatic system (Ketchum, 1951; Dyer, 1973; Monsen et al., 2002; Deleersnijder et al., 2006; Valle-Levinson, 2010). The age is the time necessary for a water parcel to travel from a defined inlet boundary (e.g. the salinity intrusion limit or the tidal intrusion limit) to another specific location (e.g. the estuary mouth; Monsen et al., 2002). The residence time is generally defined as the time necessary for a water particle to exit the domain for the first time (Bolin and Rodhe 1973; Zimmerman 1976; Takeoka 1984; Buffoni et al., 1997; Falco et al., 2000; Poulain and Hariri, 2013). The residence time therefore varies spatially, depending on the starting location and time. For these timescale calculations, once water particles leave the estuary they are disregarded. In practice, however, some particles may return to the estuary with reversing tidal currents, after first exiting (Monsen et al., 2002). To incorporate this process in a timescale, exposure time is used. This can be defined as the total time that a parcel of water spends inside an aquatic environment (Delhez, 2006; Andutta et al., 2012; de Brye et al. 2012; Andutta et al., 2013). The difference between the exposure time and residence time depends on the circulation in coastal waters; for instance, swift longshore currents decrease the difference between the exposure and residence times (Wolanski, 2007). Previously, residence time had been defined as the time required for the volume of an estuary to be replaced with new water from both the ocean and the river (e.g. Dyer, 1973); we propose to call this the renewal time, as the definition of residence time has now changed. Transit time is also important (Bolin and Rodhe 1973; Zimmerman 1976), and may be defined as the time taken for a particle to cross from the inflow to the outflow open boundary of the domain. Thus the 
transit time for some conditions would be similar to both the water renewal time and the residence time in the upstream location of an estuary.

These transport timescales (Fig. 1) are determined by the hydrodynamics of the system (Monsen et al., 2002; Delhez, 2006; Sheldon and Alber, 2006; Delhez and Deleersnijder, 2006; Lowe et al., 2009; Andutta et al., 2012; Andutta et al., 2013). Their precise values remain elusive, however, because the hydrodynamics are comprised not only of the water circulation, which is generally well known and can usually be modeled reliably, but also all of the unresolved processes, which are relatively unknown and generally assumed to amount to turbulent mixing.

Figure 1- Preferred position.

Estimating transport timescales, in even the simplest 1-D estuarine models, has proven to be a challenge to modelers. For an estuary located between $x=L_{1}$ (the upstream limit) and $x=L_{0}$ (the estuary mouth), where the estuarine segment length $L=L_{1}-L_{0}$, the residence time can be estimated from models using virtual passive particles. In the simplest case of cross-sectional homogeneity, and in the absence of baroclinic currents, a 1-D model may be sufficient; in which case the tracers have a concentration, $C$, that follows the equation

$$
A \frac{\partial C}{\partial t}+Q \frac{\partial C}{\partial x}=\frac{\partial}{\partial x}\left(A K \frac{\partial C}{\partial x}\right)
$$

where $A(\mathrm{x})$ is the cross-sectional area of the estuary, $t$ is the time, $x$ is the distance along-channel, $Q$ is the flow rate, and $K$ is the along-channel mean dispersion. This mean dispersion is due to numerous processes in addition to turbulence that affects the timescales of interest (i.e. multiple tidal cycles). To calculate the residence time, the modeler seeds the model with tracers so that $C=1$ at $t=0$ everywhere at $L_{0}<x<L_{1}$. Eq. (1) must be solved to calculate $C$ as a function of $x$ and $t$; from this solution the various timescales can be calculated. None of these steps, however, are straightforward. Firstly, a hydrodynamic model is required to provide the data for $Q$ as a function of $x$ and t. Secondly, the modeler must also provide a closed-form formula or a model to estimate $K$ as a function of $x$ and $t$. Thirdly, the modeler must specify the open boundary conditions for $C$ at $x=$ $L_{1}$ and $x=L_{0}$. To calculate the residence time, the open boundary conditions are in their most simple form, namely $\mathrm{C}=0$ at $x=L_{1}$ and $x=L_{0}$ (e.g. Delhez and Deleersnijder 2006). To compute the exposure time, the open boundary conditions for $C$ at $x=0$ and $x=L$ are unknown a priori; the usual practice is for the modeler to extend the model domain offshore $(x>L)$ in 2-D or 3-D, at a distance far enough that the estuary does not influence the adjacent circulation. The model should 
105

106

1407

3

1408

5

16) 9

70

9

also be extended upstream into the river (see e.g. de Brye et al. 2012). This requires knowledge of the coastal circulation, which subsequently requires knowledge of the oceanic circulation offshore. In the simplest case, three independent parameters control this timescale: the residual velocity, $u=$ $Q_{R} / A$, where $Q_{R}$ is often assumed to be the river discharge and $A$ is the cross-sectional area; the estuarine segment length, $L$; and the along-channel eddy dispersion coefficient, $K$. Two timescales result therefrom (Fischer et al., 1979), namely an advective timescale, $T_{1}=L / u=V / Q_{R}$, and a dispersive timescale, $T_{2}=L^{2} / K$. The relative importance of these two timescales is determined by their ratio, which is the Peclet number $P_{E}=T_{2} / T_{1}=u L / K$. While $P_{E}$ is used in estuarine classification schemes (Prandle, 2009), as yet no formula has been proposed to estimate the residence time of an estuary as a function of $P_{E}$. The dispersive timescale, $T_{2}$, may be expressed as $T_{2}=P_{E} V / Q_{R}$, taking into consideration the estuarine volume.

In view of these complexities, modelers have moved away from analytical solutions and have increasingly used numerical models in 2-D and 3-D. Such models are elegant, but they still carry uncertainties in terms of the hydrodynamic conditions and fate of tracers at the open boundaries. Additionally, for quantifying dispersion, adjusting the horizontal dispersion coefficient at the sub-grid scale is still a challenge (Fischer, 1969, 1974 and 1976). Although there are an increasing number of physical oceanographers modelling estuaries, residence time has been estimated with calibrated numerical models for only a few estuaries, while simple box models have been applied to over 200 estuaries.

In view of this, we propose to re-evaluate the usefulness of 1-D and box estuarine models. Historically, simple zero-dimension box models were proposed to estimate the replacement time of the estuarine volume, $V$, which was then called the residence time (Swaney et al., 2011) and turnover time (Sheldon and Alber 2006), and is now termed the renewal time. Because, under many conditions, water renewal time would be similar to residence time at the inflow open boundary (i.e. upstream estuarine location), the residence time results from calibrated numerical models would be useful to verify the efficiency of simple models. Probably the two most wellknown models of this type are the tidal flushing box model, and the gravitational circulation model (Ketchum, 1951; Dyer, 1973; Officer, 1976). The tidal flushing box model assumes that the estuary is flushed at each tidal cycle by the tidal prism, $V_{p}$, i.e. the amount of water that exits the estuary at ebb tide (Ketchum, 1951; Harleman, 1966; Officer, 1976; Dyer, 1973; Zimmerman, 1988; Luketina, 1998; Sanford, 1992; Solis and Powell, 1999; Sheldon and Alber, 2006; Figure 2b). Thus, a fraction, $r$, of the estuary water is renewed by ocean water at each tidal cycle,

$r=V_{p} / V$ 
140

141

142

3

1443

5

1644

745

185

${ }_{1}^{9} 46$

147

12

1348

14

11549

16

1150

18

19

202

22

233

24

25

2164

27

2185

29

30,56

32

3137

34

3558

36

3759

38

3900

40

4161

42

4352

44

4563

46

4764

48

49

50

51

565

53

5166

55

51657

57

5168

59

609

61

62

63

64

65
The renewal time, $T$, was calculated as

$$
T=\tau / r
$$

where $\tau$ is the tidal period (e.g. $0.5 \mathrm{~d}$ for solar semi-diurnal tide and $1 \mathrm{~d}$ for solar diurnal tide).

In an attempt to provide information on the along-channel variation of the renewal time, this model was later improved by segmenting the estuary, with the assumption that the volume of water that exits a segment at ebb tide completely replaces the water in the downstream segment (Wood, 1979). Such models do not account for the baroclinic circulation that is typical of partially mixed estuaries (Figure 2c). The gravitational circulation model calculates the renewal time as the ratio between the volume of fresh water and the inflow rate. The inflow rate is the sum of the oceanic inflow of water plus the riverine inflow (Figure 2c; Dyer, 1973); tidal mixing is neglected, and the oceanic inflow is calculated from the salt conservation equation by Knudsen (1900), which is $Q_{\text {oUT }}=Q_{I N}+Q_{R}$. Where $Q_{\text {oUT }}=Q_{R} \frac{S_{I N}}{S_{0}-S_{E}}$ and $Q_{I N}=Q_{R} \frac{S_{\text {OUT }}}{S_{0}-S_{E}} . S_{O}$ and $S_{E}$ are the salinity in coastal waters, and the average salinity in the estuary, respectively. In contrast, the salinity balance equation of Fischer (1979) states that the downstream residual transport of salt balances the upstream dispersion (diffusion) of salt, i.e. $Q \bar{S}=-K A \frac{\Delta S}{L}$, where $\Delta S=\left(S_{0}-S_{U P}\right), S_{U P}$ is the salinity at the upstream estuarine segment (i.e. salinity at the upstream inflow open boundary), and $\bar{S}$ is the mean salinity of the estuarine segment considered. If one assumes the length of the estuarine segment to be the length of the entire estuary, therefore $\bar{S}=S_{E}$.

The fresh water renewal time calculated using the gravitational circulation model, which is also called fresh water fraction model, $T_{F}$ (Hansen and Rattray, 1965; Dyer, 1973; Wolanski, 2007) is,

$$
T_{F}=\frac{V}{Q_{R}} F_{R}=\frac{V}{Q_{R}\left(\frac{S_{0}}{S_{0}-\bar{S}}\right)}=\frac{V}{Q_{R}+Q_{R} \frac{\bar{S}}{S_{0}-\bar{S}}}
$$

where $T_{F}$ is the time taken to renew the portion of fresh water in the estuary, $F_{R}=\left(S_{0}-\bar{S}\right) / S_{0}$ is the fresh water fraction (Dyer, 1973), and $Q_{R}$ is the river discharge (or total residual outflow). It is important to note that the fresh water fraction model estimates the time to renew only the fresh water portion, which is smaller than the volume of the whole domain. Therefore, the fresh water fraction model would result in a shorter timescale than the residence time of particles released near 
the estuary head. Previous simple box models neglected either baroclinic circulation or tidal mixing, and the fresh water fraction model has always been criticized for lacking seawater inflow and miscalculating transport timescales. Sheldon and Alber (2006) demonstrated that the fresh water fraction model incorporates the effect of seawater inflow, which is due to the gravitational circulation effect (Figure 2c). In general, many researchers dislike formulations that cast advective fluxes of the gravitational circulation in terms of along-channel diffusivity or similar simplified assumptions. These physical processes, i.e. dispersion, gravitational circulation etc., are governed by different physics.

Similar to the fresh water fraction model, the well-known LOICZ model (Smith et al., 2005 and 2010; Crossland et al., 2005; Swaney et al., 2011) includes both advective and exchange flow transport (Figure 2d). Sheldon and Alber (2006) demonstrated that the LOICZ model does not consider the salt conservation equation proposed by Knudsen (1900), and this manuscript shows that the LOICZ solution does not properly apply the salinity balance proposed by Fischer (1979). Therefore, there are two proposed methods that might be considered by the LOICZ scientific community.

For the LOICZ model, rainfall, groundwater and evaporation effects can also be added if required, and are incorporated into the residual flow $Q_{R}$. For a vertically well-mixed estuary, oceanic water enters the estuary at a rate, $Q_{D}$ (the exchange flow), with a salinity that exceeds the initial estuarine salinity, $S_{R}$, by the amount $\Delta S$. $Q_{D}$ applied in the LOICZ model is different from the well-known salinity balance equations by Knudsen (1900) and Fischer et al. (1979).

Figure 2- Preferred position.

The water renewal of an estuary depends upon the residual flow, e.g. river discharge $Q_{R}$, and the exchange flow $Q_{D}$. The general formulation to estimate water renewal is:

$$
T=V /\left(Q_{R}+Q_{D}\right)
$$

where $Q_{D}$ is defined as the exchange flux between the estuary and the coastal areas. We note that this term, i.e. $Q_{D}$, is called $V_{X}$ in the LOICZ model (Gordon et al., 1996); however, $Q_{D}$ seems more appropriate to represent a term denoting a large dispersive contribution to water renewal. Sheldon and Alber (2006) presented a good argument for applying a different method to estimate the exchange flow, $Q_{D}$. They used the Knudsen relation.

In summary, there are two well-known competing definitions for the salt balance, and they rely upon different physics. Knudsen relation assumes that steady salinity is balanced by residual circulation and gravitational circulation (i.e. used in the fresh water fraction model), while in the 
second definition (i.e. from Fischer formulation for the salinity balance), steady salinity is balanced by residual circulation and dispersive processes. This manuscript presents results of water renewal calculated using both methods, and compares them with results from numerical models.

Advection and dispersion of salt are balanced in a steady-state along an estuarine system, giving the salt-balance equation by Fischer et al. (1979),

$$
Q_{D}=Q_{R} S_{E} /\left(S_{O}-S_{U P}\right)
$$

In the Knudsen relation, the inputs of freshwater $Q_{R}$ and seawater $Q_{D}$ have salinities of 0 and $S_{O}$, respectively. In order to balance the water volume, an outflow of magnitude $\left(Q_{R}+Q_{D}\right)$ must exit the system, therefore the salt balance is:

$$
Q_{R} 0+Q_{D} S_{O}=\left(Q_{R}+Q_{D}\right) S_{E}
$$

which results in the exchange flow,

$$
Q_{D}=Q_{R} S_{E} /\left(S_{0}-S_{E}\right)
$$

The difference between equation (6) and (8) is due to the different assumptions regarding the salinity balance, i.e. Knudsen relation and Fischer formulation. If one applies the salinity conservation equation proposed by Knudsen relation, Eq. 5 reduces to Eq. 4, which is the fresh water fraction model. Sheldon and Alber (2006) demonstrated that the LOICZ model does not apply Knudsen relation for the salinity balance properly, because the salinity of the outflow would be $S_{E}$. The LOICZ model considers the salinity balance in the outer half of the estuary, which would result in a mass balance problem in the Knudsen relation.

The LOICZ method assumes neither Knudsen relation nor Fischer formulation for the salinity balance. Here it is demonstrated that the LOICZ model applies a salinity balance slightly different from the balance proposed by Fischer et al. (1979). For the LOCIZ model the exchange flow is,

$$
Q_{D} \Delta S=Q_{R} S_{R}
$$

the estuarine outflow salinity is,

$$
S_{R}=0.5\left(S_{O}+S_{E}\right)
$$


and mean salinity in the outer estuary (see, Gordon, et al., 1996; Dupra et al., 2001; Swaney et al., 2011) is,

\section{The LOICZ model}

The LOICZ model includes both advective and a exchange flow transport. Dispersive residual transport is calculated as an exchange flow between the estuary and coastal waters. This exchange flow is calculated by assuming the salinity gradient in the seaward half of the estuary, i.e. 
277 from the estuarine mouth $\left(x=L_{0}\right)$ to $x=L / 2$, and considering geometric features of the estuary,

including sewage, groundwater, rainfall, evaporation, freshwater runoff, as well as the salinity in the estuary and in coastal waters. The inflow water would be a result of processes such as fresh water discharge, rainfall, groundwater etc. However, to simplify the model we neglect all terms aside from river discharge. The LOICZ box model calculates the average residence time $T_{L O I C Z}$ using Eq.12. Using Eq. 10, Eq. 12 becomes,

$$
T_{\text {LOICZ }}=\frac{V}{Q_{R}+\underbrace{Q_{R} \frac{0.5\left(S_{E}+S_{O}\right)}{S_{O}-S_{E}}}_{\text {exchange flow }}} .
$$

The LOICZ model depends on accurate measurements of the salinity at the boundaries of the domain in order to properly estimate the exchange flow $\left(Q_{D}\right)$. The basic assumptions associating $Q_{D}$ with the salinity balance may be invalid if the salinity gradient is too small (Swaney et al., 2011).

Eq. 13 may be written as,

$$
T_{\text {LOICZ }}=\frac{V L}{Q_{R} L+\left(\frac{0.5\left(S_{E}+S_{O}\right)}{S_{O}-S_{E}}\right) Q_{R} L} .
$$

The salinity balance equation of Fischer et al. (1979) can be used in this case to estimate the amount of dispersion applied into the LOICZ model, and assuming the salinity at the mouth $S(L)$ to be $S(L) \approx S_{O}$,

$$
Q_{R} L=A K^{\operatorname{LOICZ}} \frac{\left(S_{O}-S_{E}\right)}{0.5\left(S_{O}+S_{E}\right)}
$$

where $K^{\text {LOICZ }}$ is the dispersive coefficient applied in the salinity balance in the LOICZ model, and $A$ is the mean cross-sectional area. It will be further shown that the LOICZ model often results in a large dispersion coefficient because it accounts for a salinity balance near the estuarine mouth. From Eqs. 14 and 15,

$$
T_{\text {LOICZ }}=\frac{V L}{Q_{R} L+A K^{L O I C Z}}
$$

In Eq. 14 the influence of the dispersive timescale on the water renewal is parameterized by $\gamma_{\text {LOICZ }}$, which is defined as, 


$$
\gamma_{\text {LOICZ }}=\left[\frac{0.5\left(S_{E}+S_{O}\right)}{S_{O}-S_{E}}\right]
$$

310

391

3912

19. 13

Using the advective and dispersive timescales (Fischer et al. 1979), as previously defined, i.e.

$$
T_{1}=\frac{V}{Q_{R}}, \quad \text { and } \quad T_{2}^{\text {LOICZ }}=\frac{L^{2}}{K^{\text {LOICZ }} . ~}
$$

Eqs. 16 and 18 become,

$$
\frac{1}{T_{\text {LOICZ }}}=\frac{1}{T_{1}}+\frac{1}{T_{2}^{\text {LOICZ }} . ~}
$$

To our knowledge, Eq. 19 has not previously been derived for the LOICZ model. This equation shows the importance of the advective and dispersive timescales for water renewal.

\section{The modified LOICZ model}

For the modified LOICZ model, we propose a modified exchange flow that takes into consideration the average dispersion, which is calculated using Fischer formulation (Fischer et al., 1979). Field data indicate that water renewal, $T$, decreases with increased dispersion (Uncles et al., 2002). The along-channel dispersive coefficient, $K$, can be estimated from salinity data along the whole estuarine segment, $L$ (Fischer et al., 1979). $K$ can be estimated from the salinity balance equation because all the other terms in that equation are measureable. Other methods exist that can be used to estimate $K$ from salinity measurements, e.g. that of Hansen and Rattray (1965), which involves choosing values of $K$ to fit the observed distribution of salinity with the analytical solution. Additional methods also exist to estimate the salinity balance and dispersion (Knudsen, 1900; MacCready, 1998; MacCready, 2004; MacCready, 2011; MacCready and Banas, 2011), which could be used to further quantify the exchange flux applied in our method.

The proposed method is also based upon Fick's first law, which relates the diffusive (dispersive) flux to the concentration under the assumption of steady state. The magnitude of the flux is proportional to the concentration gradient, from high to low. Consider a large number of particles to represent a concentration, $C$, which are initially deployed at the upstream location of the estuarine segment, $L$. Horizontal dispersion would result in a random walk in two dimensions, i.e. 
along and across the estuary. However, the movement of particles across the estuary is limited by solid boundaries, and thus dispersion of particles would be predominantely along the estuary, and the dispersive flux of particles would have two orientations (upstream and downstream). The mean square displacement $\sigma^{2}$ of particles (in one dimension) would be $\sigma^{2}=2 K_{d} \Delta t$. Note that this randon displacement of particles (towards the upstream or downstream boundaries), depends upon the small time step, $\Delta t$, and the dispersive coefficient, $K_{d}$. The coefficient $K_{d}$ determines the random walk within the time step $\Delta t$, this coefficient is not the characteristic dispersion $K$ of the whole estuarine segment $L$. In fact, it is a much smaller dispersion $\left(K_{d}<<K\right.$ ). To avoid an overestimate of the downstream movement due to dispersion, the mean square downstream displacement is assumed to be $\Delta d^{2}=\alpha \sigma^{2}$, where the reducing factor is considered to be $\alpha=1 / 2$. By assuming the displacement to be a constant under steady state conditions, the finite additivity property of displacements satisfies, $L=\sum_{j=0}^{n} \Delta d\left(\Delta t_{j}\right)=\Delta d_{1}+\Delta d_{2}+\ldots+\Delta d_{n}=n \Delta d=n \sqrt{K_{d} \Delta t}$. The dispersive timescale in this case would be $T_{2}=n \Delta t$, but also assumes the form $T_{2}=L^{2} / K$, and thus suggests that the dispersion coefficient $K$ is the finite additivity of the dispersion in each of the $\mathrm{n}$ sub-segments of length $\Delta d$, i.e. $K=n K_{d}$. The mean dispersive flux across the area, $A$, is calculated using the estuarine segment length and the dispersive timescale, i.e. $Q_{D}=L A / T_{2}$. Additionally, it can be expressed in terms of $K$ or $K_{d}$, i.e. $Q_{D}=K A / L=n K_{d} A / L$. From Fischer formulation, the dispersion, $K$, can be estimated and applied into the dispersive flux relation,

$$
Q_{D} \sim K A / L
$$

and as shown before,

$$
Q_{D}=Q_{R} S_{E} /\left(S_{O}-S_{U P}\right)
$$

where $S_{U P}$ is in the range $0 \leq S_{U P}<S_{E}$. Here $S_{U P}$ is defined at the upstream end of the domain, and depends upon the estuarine segment length, $L$. The length, $L$, can be shorter than, but cannot exceed the length of the maximum salinity intrusion; otherwise it would lead to a misapplication of the model. It can be seen when comparing Eqts. (9-10) and Eqt (21) that the LOICZ method uses a larger exchange flow, $Q_{D}$, than the modified LOICZ model. Thus we propose to use Eq. (21) as the basis of the modified LOICZ model. This gives water renewal time, $T_{P}$, as, 


$$
T_{P}=\frac{V L}{\left(Q_{R} L+A K\right)}=\frac{V L}{Q_{R} L+\left(\frac{S_{E}}{S_{O}-S^{\prime}}\right) Q_{R} L}=\frac{V P_{E}}{Q_{R}\left(1+P_{E}\right)},
$$

where $P_{E}=u L / K$ is the Peclet number, and

$$
\gamma_{P}=S_{E} /\left(S_{O}-S^{\prime}\right),
$$

$\gamma_{P}$ determines the contribution to water renewal from the dispersive timescale, and is calculated differently from $\gamma_{\text {LOICZ }}$ in the LOICZ model (Eq. 19). Using the dispersive and advective timescales, Equation 22 becomes,

$$
\frac{1}{T_{P}}=\frac{1}{T_{a}}+\frac{1}{T_{b}}
$$

where $T_{a}=V / Q_{R}$ and $T_{b}=V P_{E} / Q_{R}$ are the advective and dispersive timescales, respectively, as calculated using the river flow $Q\left(\mathrm{~m}^{3} \mathrm{~s}^{-1}\right)$. The contribution of advection to the total water renewal, $\theta(0 \leq \theta \leq 1)$, is given by

$$
\theta=T_{P} / T_{a}=Q_{R} /\left(Q_{R}+Q_{D}\right)
$$

\section{The difference between the water renewal time calculated from the LOICZ model and the modified LOICZ model}

There are some differences between the original formula used in the LOICZ model and the newly modified LOICZ model. These are parameterized by $\gamma=\gamma_{\text {LOICZ }} / \gamma_{P}$, which is the ratio between the exchange flow in the LOICZ model (Officer, 1980; Swaney et al., 2011) and the suggested new method. Assuming a linear salinity gradient along an estuary, the salinity at the mouth is related to salinity in the estuary by $S_{O}=2 S_{E}$, salinity at the maximum salinity intrusion is $S_{U P}=0$, and thus the ratio $\gamma / \gamma_{p}=3$. Therefore, for a nearly linear salinity distribution along an estuary, the dispersive timescales for the LOICZ model are expected to be three times larger than for the modified LOICZ model. The salinity balance used to calculate the so called exchange flow in the LOICZ model is described in (Fig. 3). 
402

403

404

3

495

5
469

7

487

4. 8

4709

12

1810

14

1451

16

4712

18

19

2013

21

22

23

2414

25

295

28

29

30
3116

32
33

3418

Figure 3-Preferred position.

In the LOICZ model, the exchange flux is calculated slightly differently from that proposed by Fischer et al. (1979), see Figure 3. The exchange flow from the LOICZ model is calculated using the salinity balance from $x=L / 2$ to $x=L$. Our approach was to estimate exchange flux from measurements of salinity along the estuary, using Fischer formulation, $Q_{D} \sim A K / L\left(\mathrm{~m}^{3} \mathrm{~s}^{-1}\right)$. This exchange flux, $Q_{D}$, therefore accounts for the dispersive process at steady state along the whole estuarine segment of length $L$.

To compare the contributions of the river discharge and the exchange flow to water renewal, we assume a linear variation of the along-channel salinity gradient, $S_{E}=0.5 S_{O}$ and $S_{U P}=0$. Thus equations 14 and 22 become respectively,

$$
T_{\text {LOICZ }}=\frac{V}{Q_{R}+\underbrace{1.5 Q_{R}}_{\text {exchange flow }}},
$$

and

$$
T_{P}=\frac{V}{Q_{R}+\underbrace{0.5 Q_{R}}_{\text {exchange flow }}},
$$

The exchange flow in the LOICZ formula (Eq. 26) is much larger than the exchange flow in the modified model (Eq. 27). Additionally, in the LOICZ model, the exchange flow contributes 50\% more to water renewal than river discharge does. Conversely, Eq. 27 gives an exchange flow contribution that is half of the advective term.

\section{The CART analytical model}

The Constituent-oriented Age and Residence time Theory (CART, www.climate.be/cart) consists of general partial differential problems from which a number of timescales may be derived at any time and location so as to assess water and contaminant exchange rates. For instance, the age, residence time and exposure time have been estimated numerically in realistic semi-enclosed domains such the New York Bight (Zhang et al 2010) and the Scheldt Estuary (de Brauwere et al. 2011, de Brye et al. 2012). Analytical solutions obtained in an idealised setup may also be of use. Accordingly, a one-dimensional flow with constant hydrodynamical and geometrical features shall be considered, allowing the exact solutions to be constructed for the residence and exposure times of passive tracer particles, which may also be regarded as tagged water parcels. These idealised CART timescales will be compared with the water renewal timescales ensuing from the original and 
434

435

436 4B7

5 468 7 4839 9

1440 11

1441 13 14⿻ 2 15 1643 17 1 견4ㄴ

modified LOICZ models, as well as those obtained from numerical models, for estuaries where such estimates are available.

Consider an infinite pipe $(-\infty<x<\infty)$ with a constant section $A$, in which there is a steadystate, one-dimensional current whose volumetric flow rate is denoted $Q_{R}$. The upstream and downstream boundaries of the domain of interest, i.e. the idealised estuary, are located at $x=L_{1}$ and $x=L_{0}$, respectively. The length of the estuary, its volume and the water flow are given by,

$$
L=L_{0}-L_{1}, V=A L \text { and } U=Q_{R} / A=L Q_{R} / V .
$$

The general differential problem from which the residence time may be estimated was established by Delhez et al. (2004). For the one-dimensional steady-state problem to be dealt with, the residence time $\varphi(x)$ satisfies the equation (Delhez and Deleersnijder 2006, Blaise et al. 2010)

$$
\frac{d}{d x}\left(A K \frac{d \varphi}{d x}+Q_{R} \varphi\right)=-A
$$

under the boundary conditions,

$$
\varphi\left(L_{1}\right)=0=\varphi\left(L_{0}\right)
$$

where the positive constant, $K$, denotes the along-flow diffusivity. It must be stressed that (28) is not an advection-dispersion-reaction equation; if it were an equation of this type, the advective term would be $-Q_{R} \varphi$ rather than $+Q_{R} \varphi$. In fact, the equation for the residence time is the adjoint of the relevant transport equation (Delhez et al. 2004, Delhez 2006). The physical meaning of the residence time mathematically defined above is as follows: the average time taken for water or passive tracer particles initially located in the interval $[x, x+\delta x]$ to reach one of the open boundaries of the domain for the first time (i.e. $x=L_{1}$ or $x=L_{0}$ ) tends to $\varphi(x)$ as $\delta x \rightarrow 0$. As all of the flow parameters are assumed to be constant, the solution to (28)-(29) is easily derived:

$$
\phi(x)=\frac{V}{Q_{R}}\left(1-\frac{\xi}{L}\right)+\frac{V}{Q_{R}}\left(\frac{e^{-P e}-e^{-P e \xi / L}}{1-e^{-P e}}\right)
$$

where $\xi=x-L_{1}$ and the dimensionless parameter

$$
P e=\frac{U L}{K}
$$


465

466

1

may be regarded as the Peclet number of the flow under consideration. The latter is the ratio of the dispersive timescale $T_{2}=L^{2} / K$ to the advective timescale $T_{1}=L / U$.

After crossing an open boundary, a particle may re-enter the domain at a later stage (e.g. Spivakovskaya, et al. 2007, Delhez and Deleersnijder, 2010). This is not accounted for by the residence time, which is related to the time taken to hit an open boundary for the first time. To take into account the possibility of particles returning into the domain, the concept of exposure time was introduced (Monsen, et al. 2002, Delhez, et al. 2004, Delhez, 2006). This timescale, which is denoted hereinafter $\Theta(x)$, is defined in the domain of interest and its surrounding environment, and is the solution of the equation (Delhez et al. 2004, Delhez and Deleersnijder 2006)

$$
\frac{d}{d x}\left(A K \frac{d \varphi}{d x}+Q_{R} \varphi\right)=\left\{\begin{array}{l}
-A \varphi, L_{1}<x<L_{0} \\
0,-\infty<x \text { or } L_{0}<x<\infty
\end{array}\right.
$$

The solution thereof is

$$
\begin{array}{lll}
-\infty<x \leq L_{1}: & \Theta(x)=\frac{V}{Q_{R}} \\
L_{1} \leq x \leq L_{0}: & \Theta(x)=\frac{V}{Q_{R}}\left(1-\frac{\xi}{L}\right)+\frac{V}{Q_{R}}\left(\frac{1-e^{-P e \xi / L}}{P e}\right) \\
L_{0} \leq x<\infty \quad: & \Theta(x)=\frac{V}{Q_{R}}\left(\frac{e^{P e}-1}{P e} e^{-P e \xi / L}\right)
\end{array}
$$

The physical meaning of the exposure time is as follows: the average time that water or passive tracer particles initially located in the interval $[x, x+\delta x]$ will spend in the domain of interest $\left(L_{1}<x<L_{0}\right)$ tends to $\Theta(x)$ as $\delta x \rightarrow 0$.

Figure 4- Preferred position.

Figure 4 displays the profile of the residence and exposure time for various values of the Peclet number. For high values of the Peclet number, the boundary layer for the concentration, $C$, is 
495

developed in the vicinity of the upstream boundary of the domain (Delhez and Deleersnijder 2006, Blaise et al. 2010). The cause thereof may be summarized as follows: the greater the relative importance of advection, the less likely it is that dispersion will cause a water particle to hit the upstream boundary of the domain $\left(x=L_{0}\right)$. In accordance with elementary physical intuition, the exposure time is larger than the residence time $\left(L_{1} \leq \xi / L \leq L_{0}\right)$.

It is appropriate to assess the propensity of water particles to return into the domain after hitting one of its open boundaries for the first time. For this, we used the approach of Arega et al. (2008) and de Brauwere et al. (2011), which leads to the dimensionless number termed "return coefficient". This is defined as

$$
r(x)=\frac{\Theta(x)-\phi(x)}{\Theta(x)}
$$

The values of this coefficient (Eq. 34) fall within the interval [0,1]: the larger this value, the more likely it is that water particles will re-enter the domain after hitting one of its open boundaries for the first time. Accordingly, particles that never return into the domain are characterized by a zero return coefficient, while particles returning most often are associated with a value of $r$ that is close to unity (Fig 5).

Figure 5- Preferred position.

From Equations 30 and 33, the domain-averaged residence time and exposure times obey the relations,

$$
\bar{\phi}=\frac{V}{Q_{R}}\left(\frac{1}{2}\right)+\frac{V}{Q_{R}}\left(\frac{1}{e^{P e}-1}-\frac{1}{P e}\right)
$$

and

$$
\bar{\Theta}=\frac{V}{Q_{R}}\left(\frac{1}{2}\right)+\frac{V}{Q_{R}}\left(\frac{1}{P e}-\frac{1-e^{-P e}}{P e^{2}}\right) .
$$

These global timescales can also be regarded as the residence and exposure times of an arbitrarily large number of water particles that initially are uniformly distributed over the domain. The first terms in Equations 35 and 36 are the mean advective timescales, while the second terms cause the decrease and increase to the final residence time and exposure time.

\section{Results and discussions}


The CART model, the LOICZ model, the fresh water fraction model, and a newly modified

LOICZ model were applied to the estuaries (Appendix 1 to 7), namely the Curimataú, Caravelas and Peruípe estuaries in Brazil (Miranda et al., 2005 and 2006; Andutta et al., 2006), the York River and Hudson estuaries in the USA (Sandifer, 1973; Haas, 1977; Shen and Haas, 2004; Warner et al., 2005 and 2010), the Conwy and Mersey estuaries in the UK (Bowden and Gilligan, 1971; Turrell et al., 1996; Wu et al., 2005), and the Scheldt in France-Belgium-Netherlands (de Brauwere et al., 2011; de Brye et al., 2012). Water renewal times were estimated using the LOICZ model, the modified LOICZ model and the fresh water fraction model, while the CART theory was applied to estimate the mean residence and exposure times.

From Table 1 it can be seen that water renewal times calculated by the LOICZ method and the fresh water fraction model are always shorter than those calculated from the modified LOICZ model, $T_{P}$. Results from the fresh water fraction model, $T_{F R A C}$, were often similar to results from the

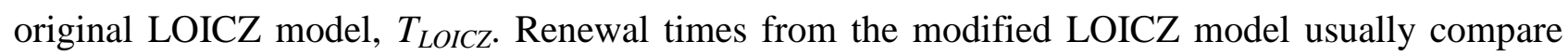
well with the exposure times calculated by the CART analytical model (see Table 2). Timescales from the LOICZ model are shorter than those from the modified LOICZ model, due to the larger dispersive coefficient applied in the original model (explained in section 4). Additionally, timescales from the fresh water fraction model are shorter than those from the proposed LOICZ model, because of the larger gravitational circulation contribution to water renewal.

For the Hudson River the water renewal at neap tides ranges between 6.3 and 7.8 days for $T_{P}$, and ranges between 4.3 and 5.3 days using the LOICZ model, while water renewal from the fresh water fraction model ranges between 5.9 and 7.4 days for neap tides, and between 6.7 and 8.5 days for spring tides.

The difference in $T$ between the original and the proposed LOICZ models comes from the dispersive timescale component, which in this case ranges from 31.4-43.0 days using the modified LOICZ model, and from 9.4 - 12.1 days using the original LOICZ model. This difference in the dispersive timescales depends upon on the coefficient, $K$, which was estimated to range between 1880 to $2404 \mathrm{~m} \mathrm{~s}^{-2}$ for the original LOICZ model, and 545 to $828 \mathrm{~m} \mathrm{~s}^{-2}$ for the modified LOICZ. Water renewal results from the modified LOICZ model compare favourably with exposure time estimates from the CART formula, however they are slightly underestimated compared with the numerical results for the Hudson Estuary (Warner et al., 2010), which give a mean residence time for neap tides of $\sim 8$-10 days and for spring tides $\sim 8-9$ days.

The water renewal time in our proposed method is a combination of advective and dispersive timescales, and the difference between $T_{P}$ and $T_{L O I C Z}$ depends on the factor $\gamma$. This is especially the case when the advective timescale is relatively large compared to the dispersive 
563 timescale, and thus the dispersive timescales dominate the renewal time. For the Mersey estuary,

the advective timescale is very large compared with the dispersive timescale, and the water renewal calculated by the original LOICZ model is considerably less than that of the modified LOICZ model. Conversely, for the Hudson estuary during neap tides, the fresh water discharge is important, and thus the advective timescale is smaller than the dispersive timescale, $T_{\text {LOICZ }}$ approaches $T_{P}$.

The residence times calculated by the CART formula were mostly smaller than the results for water renewal calculated using the LOICZ model, the fresh water fraction model, and the modified LOICZ model. In contrast, CART exposure times were always larger than the residence times from numerical models; this is because of how these timescales are defined. CART exposure times are, however, more comparable to the water renewal times in most cases. Larger exposure times result from the small values of the Peclet number (Table 2). Therefore, high values of the Peclet number indicate that although particles may reach the open boundary quickly, they may return to the system for long periods (e.g. Curimataú, Caravelas, Peruípe and Mersey estuaries).

The results of these different approaches (i.e. $T_{P}, T_{L O I C Z}, T_{F R A C}$, and CART formula) were compared with available numerical results (Table 2) for the Hudson Estuary (Warner et al., 2010), the Caravelas and Peruípe estuaries (Andutta, 2011), the Mersey Estuary (Yuan et al., 2007), the Scheldt Estuary (de Brauwere et al., 2011; de Brye et al., 2012), and the York River Estuary (Shen and Haas, 2004). The models had previously been calibrated and validated with salinity measurements, and hence, may be assumed to accurately reproduce advective and dispersive transport phenomena for the domains in which they were used.

The numerical results from (Warner et al., 2010) showed that for the Hudson Estuary (within $45 \mathrm{~km}$ of the mouth) the mean residence time for neap tides was $\sim 8-10$ days and for spring tides was $\sim 8$-9 days. The results calculated for $T_{P}$ (see Table 1 ) are slightly lower than the numerical model results for neap tides, and relatively close for spring tides (i.e 6.3-7.8 days for neap tides and 7.9-9.8 for spring tides). As mentioned previously, for the Hudson Estuary the LOICZ model and the fresh water fraction model yield a water renewal ( $\sim 5$ days) $c a .40 \%$ lower than the residence time from numerical models. For the Caravelas and Peruípe estuaries in Brazil, the residence time calculated from numerical models varied in the ranges of 4.2-10.3 and 1.5-2.5 days, respectively. For the Mersey and Scheldt estuaries, the residence time varied between 0.7-4 and 5-70 days, respectively. For the York River Estuary, the residence time varied between 11.3-33.3 and 18.159.3 days for high and mean flow, respectively. Except for the Mersey Estuary, the results from numerical models agreed well with the water renewal estimates from the modified LOICZ model (i.e. the model using Fischer formulation for the salinity balance), and were slightly higher than the water renewal estimates from the original LOICZ model, the fresh water fraction model, and the residence time estimates calculated by the CART formula. 
Table 1- Preferred position.

691 Table 2-Preferred position.

5

6 (\$) 2

603

for 4

125

1606

14

156) 7

16

6008

180

19

20

231

264 2

The modified LOICZ model provided the best fit with results of average maximum residence time from numerical models (Fig. 6a), with $\mathrm{r}^{2} \sim 0.7$. The slope was calculated to be 0.52 , indicating that the modified LOICZ model yields water renewal slightly larger than residence times from numerical models at upstream locations. Although the compared timescales have slightly different definitions, this method offers a simple way to easily estimate the residence time for which minimal oceanographic data are available (i.e. geometry, river discharge and salinity measurements).

Linear correlation of water renewal times from both the original LOICZ model and the fresh water fraction model with the residence times from numerical models resulted in $r^{2}<0.30$. Linear correlation between residence time from numerical models and the time of exposure from CART formula resulted in $\mathrm{r}^{2}$ smaller than 0.20 .

The dispersive contribution to water renewal (i.e. 1 - $\theta$ ) showed a strong exponential correlation against results of the return coefficient (Fig. 6b), with $\mathrm{r}^{2}=0.85$, indicating that estuaries dominated by dispersion may have long periods of return for water particles.

Figure 6- Preferred position.

The relative contribution to water renewal for a particular estuary, from the advective and dispersive processes, can be visualized in the Advection-Dispersion Diagram (Figure 7), which is generated using equations 24 and 25 . The parameter $\theta$, represented by straight lines, indicates the relative advective contribution to water renewal varying in the range $0 \leq \theta \leq 1$. The diagonal line $\theta$ $=0.5$, separates the areas where transport is dominated by dispersion (diagram lower zone, $\theta<0.5$ ) and advection (diagram upper zone, $\theta>0.5$ ). Although the results in figure 7 were obtained from table 1, this diagram synthesises the results into a single image. This allows an easy graphical comparison to be made between different estuaries, and between different conditions for a particular estuary. It can be seen that for the Curimataú Estuary, dispersion dominated over advection at spring tides, while advection dominated over dispersion at neap tides. The absolute, but not the relative, estimates of these timescales varied somewhat depending on which of the two methods for estimating $K$ was used (e.g. Hansen-Rattray or Fischer formulations). For the Hudson Estuary, during both neap and spring tides, the water renewal was predominantly caused by advection, 0.72 
$<\theta<0.82$. In the Conwy Estuary there was a slight dominance of advection during neap tides $\theta \sim$ 0.63, and dispersion during spring tides $\theta \sim 0.45$. For the Mersey, York, Caravelas and Peruípe estuaries, dispersion dominated over advection ( $\mathrm{ca} \theta<0.50)$, while for the Scheldt Estuary, advection and dispersion contributed nearly equally to water renewal $\theta \sim 0.50$.

In the Conwy Estuary, where the river inflow was nearly constant, the relative contribution of dispersion increased from neap to spring tides. This occurred because dispersion increases with increasing values of the ratio of the tidal oscillation $(R)$ over the mean depth $(h)$, i.e. $R / h$ (Uncles et al., 2002). This effect might be more apparent if the advective timescale, due to river discharge, is large, i.e. during low river discharge rates. Estuaries with high ratio values $R / h$ may have a greater dispersive contribution, e.g. the Curimataú Estuary $(R \sim 2.5 \mathrm{~m}$ and $h \sim 6 \mathrm{~m})$, the Caravelas $(h \sim 6.5$ m) and Peruípe $(h \sim 7.5 \mathrm{~m})$ estuaries with the maximum tidal range $(R)$ of $\sim 2.5$ meters, and the Mersey estuary $(h \sim 16 \mathrm{~m})$ forced by a tidal range $(R)$ of up to $\sim 10.5$ meters. Therefore, a larger dispersive contribution may result in a larger time of exposure (see Table 2), and thus a return coefficient close to unity. Field data suggest that water renewal, $T$, decreases with increasing tidal range, and increases with increasing estuary length (Uncles et al., 2002).

Figure 7- Preferred position.

\section{Summary and Conclusions}

We have developed a new method to quantify the relative contribution of advection and dispersion to water renewal in estuaries, using simple measurements of the river flow $Q_{r}\left(\mathrm{~m}^{3} \mathrm{~s}^{-1}\right)$, the estuary volume $V\left(\mathrm{~m}^{3}\right)$ and length $L(\mathrm{~m})$, estimates of the mean salinity $S_{E}$, and the salinity at the inflow $S^{\prime}$ (at, $x=L_{1}$ ) and outflow $S_{O}\left(\right.$ at, $x=L_{0}$ ) boundaries. Such data are available for most estuaries worldwide. From this method, estuaries may be categorized using the AdvectionDispersion diagram (Figure 7); they can be divided into those which are dominated by dispersion (e.g. Mersey Estuary), those dominated by advection (e.g. Hudson Estuary), and those for which dispersion and advection are of similar magnitude (e.g. Conwy Estuary). The model is applicable to estuaries that have simple geometries and that lack significant baroclinic circulation.

Sheldon and Alber (2006) noted that the application of $S_{R}$ was inconsistent with the compartmentalization for the LOICZ model, of which the salinity balance was inconsistent with the application of both Knudsen relation and Fischer formulation. Using $S_{R}$ resulted in a higher salinity exportation by $\mathrm{Q}_{\mathrm{D}}$ (also called $V_{X}$ in LOICZ model), which resulted in a short water renewal time. We showed that that the Land Ocean Interaction Costal Zone model uses similar equation as from the Fresh Water Fraction model, and thus often resulting in shortened transport timescales. 
The proposed modified LOICZ method can be used to study the impact of spring-neap tidal

fluctuations and seasonal variations of river flow and tides on water renewal. For example, in the Curimataú, high river flows occur mostly in summer during the wet season, whereas low river flows occur mainly in winter. For such systems, the river discharge may remain nearly constant for several weeks, and the relative contribution of dispersion and advection to the estuarine residence time would change along the spring-neap tidal cycle. In contrast, results of the Conwy estuary showed a nearly equal contribution of advection and dispersion at neap and spring tides. In the Hudson estuary, the residence time was dominated by advection, while dispersion dominated in the Caravelas, Peruípe, Mersey and Scheldt estuaries. .

Timescales calculated using the LOICZ model were always smaller than those from the modified LOICZ model and from hydrodynamic models. The reason being the method used to calculate the exchange flow in the LOICZ model; based upon Fischer formulation the exchange flow is calculated based upon the salt balance in the first half of the estuary, near the mouth, in which most dispersion is expected to occur. We know, however, that this large dispersion considered in the exchange flow would result in an underestimation of the water renewal time. The difference in the exchange flow between the LOICZ model and our proposed method depends upon the factor $\gamma$, which determines the dispersion contribution to the water renewal time. By using the equation of salt balance, proposed by Fischer et al. (1979), we have developed a new exchange flow that may be used in the LOICZ model, and which reduces the dispersion coefficient applied to the estuary. In addition, it has been demonstrated that the LOICZ model uses neither Knudsen relation nor Fischer formulation for the salinity balance.

Results from CART theory have shown that the exposure times were comparable to the residence times estimated using numerical models, while the mean residence times calculated using the CART formula were usually lower than numerical model estimates. In most cases, the water renewal times estimated using the newly proposed modified LOICZ model provided the best fit with the mean maximum residence time from hydrodynamic models, with $\mathrm{r}^{2}=0.70$. The return coefficient calculated from CART theory showed good correlation with the dispersion contribution, with $r^{2}=0.66$. Our study adds value to the LOICZ formulation as we have made improvements to estimate the water renewal timescales.

\section{Acknowledgements}

This study was supported by the IPRS fellowship to FPA. The authors greatly acknowledge kind assistance of Dr. L. de Miranda, Dr. E. Wolanski and Dr. L. Lucas. Eric Deleersnijder is an honorary research associate with the Belgian Fund for Scientific Research (FNRS) and his 
contribution to the present study was achieved in the framework of the Interuniversity Attraction Pole TIMOTHY, which was funded by BELSPO (www.belspo.be) under contract IAP6.13.

\section{References}

Andutta, F.P, Miranda, L.B., Castro, B.M., Fontes, R.F.C., 2006. Numerical Simulation of the Hydrodynamic in the Curimataú Estuary, RN Brazil. Oceanography and Global Changes, SP-Brazil, 545-558.

Andutta, F.P., 2011. The estuarine system of the Caravelas and Peruípe rivers (Bahia): Observations, simulations, residence time, and advective and diffusive processes, $\mathrm{PhD}$ Thesis. IO-USP, Oceanography Institute of the University of São Paulo, 121p.

Andutta, F.P., Kingsford, M.J., Wolanski, E., 2012. 'Sticky water' enables the retention of larvae in a reef mosaic. Estuarine, Coastal and Shelf Science 101, 54-63.

Andutta, F.P., Ridd, P.V., Wolanski, E., 2013. Age and the flushing time in the Great Barrier Reef coastal waters. Continental Shelf Research 53, 11-19.

Arega, F., Armstrong, S., Badr, A.W., 2008. Modeling of residence time in the East Scott Creek Estuary, South Carolina, USA. Journal of Hydro-environment Research 2, 99-108.

Blaise, S., de Brye, B., de Brauwere, A., Deleersnijder, E., Delhez, E.J.M., Comblen, R., 2010. Capturing the residence time boundary layer - Application to the Scheldt Estuary, Ocean Dynamics 60, 535-554.

Bolin, B., H. Rodhe, 1973. A note on the concepts of age distribution and transit time in natural reservoirs, Tellus 25, 58-62.

Bowden, K.F. and Gilligan, R.M., 1971. Characteristic features of estuarine circulation as represented in the Mersey Estuary. Limnology and Oceanography 16(3), 490-502.

Breitburg, D.L., Hondorp, D.W., Davias, L.A., Diaz, R.J., 2009a. Hypoxia, nitrogen, and fisheries: integrating effects across local and global landscapes. Annual Review of Marine Science 1, 329-349.

Breitburg, D.L., Davias, L.A., Limburg, K.E., Swaney, D.P., 2009b. Linking Nutrients, Hypoxia, Fisheries, and Fishes: Interim Report from a Workshop supported by LOICZ. LOICZ Inprint 2009/2,13-14.

Buffoni, G., Falco, P., Griffa A., Zambianchi, E., 1997. Dispersion processes and residence times in a semi-enclosed basin with recirculating gyres: An application to the Tyrrhenian Sea, Journal of Geophysical Research 102(C8), 18699-18713, doi:10.1029/96JC03862.

Crossland, C.J., Kremer, H.H., Lindeboom, H.J., Marshall Crossland, J.I., Le Tissier, M.D.A., 2005. Coastal Fluxes in the Anthropocene. Springer-Verlag, Berlin, 231 pp. 
Deleersnijder, R., Beckers, J.M., Delhez, E.J.M., 2006. On the behaviour of the residence time at the bottom of the mixed layer. Environmental Fluid Mechanics 6, 541-547.

Delhez, E.J.M., Heemink, A.W., Deleersnijder, E., 2004. Residence time in a semi-enclosed domain from the solution of an adjoint problem, Estuarine, Coastal and Shelf Science 61, 691-702.

Delhez, E.J.M., 2006. Transient residence and exposure times. Ocean Science 2, 1-9.

Delhez, E.J.M. and Deleersnijder, E., 2006. The boundary layer of the residence time field, Ocean Dynamics 56, 139-150.

Delhez, E.J.M., Deleersnijder, E., 2010. Residence time and exposure time of sinking phytoplankton in the euphotic layer, Journal of Theoretical Biology 262, 505-516.

de Brauwere, A., de Brye, B., Blaise, S., Deleersniider, E., 2011. Residence time, exposure time and connectivity in the Scheldt Estuary. Journal of Marine Systems 84, 85-95.

de Brye, B., de Brauwere, A., Gourgue, O., Delhez, E.J.M., Deleersnijder, E., 2012. Water renewal timescales in the Scheldt Estuary. Journal of Marine Systems 94, 74-86.

Dyer, K.R., 1973. Estuaries: a Physical Introduction. Wiley, London.

Dupra, V., Smith, S.V., Marshall Crossland, J.I. and Crossland, C.J., 2001. Estuarine systems of sub-Saharan Africa: carbon, nitrogen and phosphorus fluxes. LOICZ Reports \& Studies No. 18, i +83 pages, LOICZ, Texel, The Netherlands.

Falco, P., Griffa, A., Poulain, P.-M., Zambianchi, E., 2000. Transport properties in the Adriatic Sea as deduced from drifter data, Journal of Physical Oceanography 30, 2055-2071.

Fischer, H.B., 1969. Cross-sectional time scales and dispersion in estuaries. Proc. Congr. Int. Assoc. Hydraul. Res., $13^{\text {th }} 3,173-80$.

Fischer, H.B., 1974. Numerical modelling of dispersion in estuaries. Int. Symp. On Discharge of Sewage from Sea Ouifalls, London. Pap. 37, 1-8.

Fischer, H.B., 1976. Mixing and dispersion in estuaries. Annual Rev. Fluid Mechanics 8, 107-133.

Fischer, H.B., List, E.Y., Koh, R.C.Y., Imberger, J., Brooks, N.H., 1979. Mixing in Inland and Coastal Waters. Academic Press, New York, 483 pp.

Gordon, Jr.D.C., Boudreau, P.R., Mann, K.H., Ong, J.-E., Silvert, W.L., Smith, S.V. Wattayakorn, G., Wulff, F., Yanagi, T., 1996.. LOICZ biogeochemical modelling guidelines. Land-Ocean Interactions in the Coastal Zone, LOICZ Reports and Studies 5. Texel, The Netherlands.

Haas, L.W., 1977. The effect of the spring-neap tidal cycle on the vertical salinity structure of the James, York and Rappahannock Rivers, Virginia, U.S.A. Estuarine and Coastal Marine Science 5, 485-496.

Hansen, D.V. and Rattray, Jr.M., 1965. Gravitational circulation in straits and estuaries. Journal of Marine Research 23(1), 102-122.

Harleman, D.R.F., 1966. Pollution in estuaries. In Estuary and Coastline Hydrodynamics, 
Engineering Society Monographs, Chap. 14. McGraw-Hill, New York.

Ketchum, B.H., 1951. The exchanges of fresh and salt water in tidal estuaries. Journal of Marine Research 10, 18-38.

Knudsen, M. 1900. Ein Hydrographische Lehrsatz, Annalen der Hydrographie und Marinen Meteorologie 28, 316-320.

Lowe, R. J., Falter, J. L., Monismith, S. G., Atkinson, M. J., 2009. A numerical study of circulation in a coastal reef lagoon system, Journal of Geophysical Research 114(C06022), 1-18.

Lucas, L.V., Thompson, J.K., Brown, L.R., 2009. Why are diverse relationships observed between phytoplankton biomass and transport time? Limnology and Oceanography 54, 381-390.

Luketina, D., 1998. Simple tidal prism models revisited. Estuarine Coastal and Shelf Science 46, 77-84.

MacCready, P., Banas, N.S., 2011. Residual Circulation, Mixing, and Dispersion. In: Wolanski E and McLusky DS (eds.) Treatise on Estuarine and Coastal Science, Vol 2, pp. 75-89. Waltham: Academic Press.

MacCready, P., 2011. Calculating Estuarine Exchange Flow Using Isohaline Coordinates, Journal of Physical Oceanography 41, 1116-1124.

MacCready, P., 2004. Toward a Unified Theory of Tidally-Averaged Estuarine Salinity Structure, Estuaries 27(4), 561-570.

MacCready, P., 1998. Estuarine Adjustment to Changes in River Flow and Tidal Mixing 29, 708726.

McLusky, D.S., Elliott, M., 2004. The Estuarine Ecosystem: Ecology, Threats and Management. OUP, Oxford, $214 \mathrm{pp}$.

Miranda, L.B., Bérgamo, A.L., Castro, B.M., 2005. Interactions of river discharge and tidal modulation in a tropical estuary, NE, Brazil. Ocean Dynamics 55, 430-440.

Miranda, L.B., Bérgamo, A.L., Silva, C.A.R., 2006. Dynamics of a Tropical Estuary: Curimataú River, NE Brazil. Journal of Coastal Research SI 39, 697-701.

Monsen, N.E., Cloern, J.E., Lucas, L.V., Monismith, S.G., 2002. A Comment on the Use of Flushing Time, Residence Time, and Age as Transport Timescales. Limnology and Oceanography 47, 154-1553.

Newton, A., Icely, J., 2007. Land Ocean Interactions in the Coastal Zone, LOICZ: Lessons from Banda Aceh, Atlantis, and Canute. Estuarine, Coastal and Shelf Science 77, 181-184.

Officer, C.B., 1976. Physical Oceanography of Estuaries (and Associated Coastal Waters). Wiley, London.

Officer, C.B., 1980. Box models revisited, pp. 65-114. In P. Hamilton and K. B. Macdonald (eds.), Estuarine and Wetland Processes with Emphasis on Modeling. Plenum Press, New York. 
Poulain, P.-M. and Hariri, S., 2013. Transit and residence times in the surface Adriatic Sea as derived from drifter data and Lagrangian numerical simulations, Ocean Science Discussions 10, 197-217, doi:10.5194/osd-10-197-2013.

Prandle, D., 2009. Estuaries: Dynamics, Mixing, Sedimentation and Morphology. Cambridge University Press, Cambridge, 236 pp.

Sandifer, P.A., 1973. Distribution and abundance of Decapod Crustacean larvae in the York. Chesapeake Science 14(4), 235-257.

Sanford L.P., Boicourt, W.C., Rives, S.R., 1992. Model for estimating tidal flushing of small embayments. Journal of Waterway, Port, Coastal, and Ocean Engineering 118, 635-654.

Schettini, C.A.F., Miranda, L.B., 2010. Circulation and suspended particulate matter transported in a tidally dominated estuary: Caravelas Estuary, Bahia, Brazil. Brazilian Journal of Oceanography 58(10), 1-11.

Sheldon, J.E., Alber M., 2006. The Calculation of Estuarine Turnover Times Using Freshwater Fraction and Tidal Prism Models: A Critical Evaluation. Estuaries and Coasts 29, 133-146.

Shen, J., Haas, L., 2004. Calculating and the residence time in the York River using threedimensional model expiriments. Estuarine, Coastal and Shelf Sciences 61, 449-461.

Smith, S.V., Buddemeier, R.W., Wulff, F., Swaney, D.P., 2005. C, N, P Fluxes in the Coastal Zone. Chapter 3 in: Crossland, C.J.; Kremer, H.H.; Lindeboom, H.J.; Marshall Crossland, J.I.; Le Tissier, M.D.A. (eds). Coastal Fluxes in the Anthropocene. The Land-Ocean Interactions in the Coastal Zone Project of the International Geosphere-Biosphere Programme. SpringerVerlag, Berlin Heidelberg.

Smith, S.V., D.P. Swaney, D.P., Talaue-McManus, L. 2010. Carbon-Nitrogen-Phosphorus Fluxes in the Coastal Zone: The LOICZ Approach to Global Assessment. Chapter 14 (pp 575-586) in: Carbon and Nutrient Fluxes in Continental Margins A Global Synthesis Series: Global Change The IGBP Series. Liu, K.-K.; Atkinson, L.; Quiñones, R.; Talaue-McManus, L. (Eds.) 2010, XXVIII, 744 pp.

Solis, R.S. Powell, G.L., 1999. Hydrography, mixing characteristics, and residence times of Gulf of Mexico estuaries, p. 29-61. In T. S. Bianchi, J. R. Pennock, and R. R. Twilley (eds.), Biogeochemistry of Gulf of Mexico Estuaries. John Wiley and Sons, New York.

Spivakovskaya, D., Heemink, A.W., Deleersnijder, E., 2007. The backward Ito method for the Lagrangian simulation of transport processes with large space variations of the diffusivity, Ocean Science 3, 525-535.

Swaney, D.P., Smith S.V., Wulff, F., 2011. The LOICZ Biogeochemical Modeling Protocol and its Application to Estuarine Ecosystems. In: Wolanski E and McLusky DS (eds.) Treatise on Estuarine and Coastal Science 9, 135-159. Waltham: Academic Press. 
Takeoka, H., 1984. Fundamental concepts of exchange and transport timescales in a coastal sea, Continental Shelf Research 3, 311-326.

Turrell, W.R., Brown, J., Simpson, J.H., 1996. Salt Intrusion and Secondary Flow in a Shallow, Well-mixed Estuary. Estuarine, Coastal and Shelf Science 42, 153-169.

Uncles, R.J., Stephens, J.A., Smith, R.E., 2002. The dependence of estuarine turbidity on tidal intrusion length, tidal range and residence time. Continental Shelf Research 22, 1835-1856.

Valle-Levinson, A., 2010. Comtemporary Issues in Estuarine Physics. Cambridge University Press, United Kingdom, 315 pp.

Yanagi, T., 2000. Simple method for estimating Vx from mixing equations in a 1-dimensional, steadystate system for LOICZ biogeochemical modelling. Pages 108-110 in Dupra, V., Smith, S.V., Marshall Crossland, J.I. and Crossland, C.J. 2000. Estuarine systems of the East Asia region: carbon, nitrogen and phosphorus fluxes. LOICZ Reports and Studies 16, LOICZ, Texel, The Netherlands, $127 \mathrm{pp}$.

Yuan, D., Lin, B., Falconer, R.A., 2007. A modelling study of residence time in a macro-tidal estuary. Estuarine Coastal and Shelf Sciences 71, 401-411.

Warner, J.C., Geyer, W.R., Lerczak, J.A., 2005. Numerical modeling of an estuary: A comprehensive skill assessment. Journal of Geophysical Research 110(C05001), 1-13.

Warner, J.C., Geyer, R.W. and Arango, H.G., 2010. Using a composite grid approach in a complex coastal domain to estimate estuarine residence time. Computers and Geosciences Computers \& Geosciences 36, 921-935.

Wolanski, E., 2007. Estuarine Ecohydrology. Elsevier, Amsterdam, 157 pp.

Wood, T.J., 1979. A modification of existing simple segmented tidal prism models of mixing in estuaries. Estuarine, Coastal and Shelf Science 8, 339-347.

Wu, Y., Falconer, R.A, Lin, B., 2005. Modelling tracer metal concentration distribution in estuarine waters. Estuarine, Coastal and Shelf Science 64, 699-709.

Zhang W.G., Wilkin J.L., Schofield, O.M.E., 2010. Simulation of water age and residence time in New York Bight. Journal of Physical Oceanography 40, 965-982.

Zimmerman, J.T.F., 1976. Mixing and flushing of tidal embayments in the western Dutch Wadden Sea. Part I: Distribution of salinity and calculation of mixing timescales, Netherlands Journal of Sea Research 10, 149-191.

Zimmerman, J.T.F., 1988. Estuarine residence times, p. 75-84. In B. Kjerfve (ed.), Hydrodynamics of Estuaries, Volume 1: Estuarine Physics. CRC Press, Boca Raton, Florida. 
Table 1 - Water renewal timescale (days) of the Curimataú, Caravelas, Peruípe, Hudson, Conwy, Scheldt and York estuaries. For the Curimataú Estuary, A denotes the dispersive timescale using $K$ calculated from Fisher's formula while B uses Hansen-Rattray's formula. The advection contribution to water renewal is $\theta=T_{P} / T_{a}$ and $\theta_{\text {LOICZ }}=T_{\text {LOICZ }} / T_{2}^{\text {LOICZ }}$. The coefficient $k^{\text {LOICZ }}$ was estimated using $K^{\text {LOICZ }}=L Q_{R} 0.5\left(S_{O}+S_{E}\right) / A\left(S_{O}\right.$ $\left.-S_{E}\right)$, and $k$ was estimated using $K=L Q_{R} S_{E} / A\left(S_{O}-S^{\prime}\right)$.

\begin{tabular}{|c|c|c|c|c|c|c|c|c|c|c|}
\hline \multicolumn{11}{|c|}{ Curimataú Estuary } \\
\hline Conditions & $T_{2}$ & $T_{2}^{\text {LOICZ }}$ & $T_{1}$ & $T_{P}$ & $T_{\text {LOICZ }}$ & $T_{F R A C}$ & $\Theta$ & $\Theta_{\text {LOICZ }}$ & $k\left(m^{2} s^{-1}\right)$ & $k^{\operatorname{LOICZ}}\left(m^{2} s^{-1}\right)$ \\
\hline (A) neap tides & $2.4-4.7$ & $0.5-1.0$ & $1.4-2.4$ & $0.9-1.6$ & $0.5-0.9$ & $0.6-1.2$ & $0.64-0.67$ & $0.36-0.38$ & $245-480$ & $735-1600$ \\
\hline (B) neap tides & $2.3-4.6$ & $0.5-1.0$ & $1.4-2.4$ & $0.9-1.6$ & $0.5-0.9$ & $0.6-1.2$ & $0.50-0.67$ & $0.36-0.38$ & $250-500$ & - \\
\hline (A) spring tides & $1.8-3.3$ & $0.5-1.4$ & $4.3-7.1$ & $1.2-2.2$ & $0.5-1.4$ & $0.5-1.6$ & $0.30-0.31$ & $0.11-0.20$ & $352-656$ & $653-2267$ \\
\hline (B) spring tides & $1.7-2.7$ & $0.5-1.4$ & $4.3-7.1$ & $1.2-2.0$ & $0.5-1.4$ & $0.5-1.6$ & $0.27-0.28$ & $0.11-0.20$ & $435-700$ & - \\
\hline \multicolumn{11}{|c|}{ Caravelas Estuary } \\
\hline neap tides & $9.5-70.5$ & $3.2-45.8$ & $55.6-388.9$ & $8.1-59.7$ & $3.0-40.9$ & $3.1-43.2$ & $0.14-0.15$ & $0.05-0.11$ & 24-179 & $37-552$ \\
\hline spring tides & $7.2-51.9$ & $3.0-32.7$ & $55.6-388.9$ & $6.4-45.8$ & $2.9-30.2$ & $2.9-31.4$ & $0.11-0.12$ & $0.05-0.08$ & $31-227$ & $49-525$ \\
\hline \multicolumn{11}{|c|}{ Peruípe Estuary } \\
\hline neap tides & $1.8-4.4$ & $0.3-2.7$ & $2.3-13.9$ & $0.5-3.3$ & $0.3-2.3$ & $0.3-2.5$ & $0.22-0.24$ & $0.13-0.17$ & $66-427$ & $107-1035$ \\
\hline spring tides & $0.3-1.7$ & $0.1-1.4$ & 2.3-13.9 & $0.2-1.5$ & $0.1-1.2$ & $0.1-1.3$ & $0.09-0.11$ & 0.04-0.09 & $173-1071$ & $212-1938$ \\
\hline \multicolumn{11}{|c|}{ Hudson Estuary } \\
\hline neap tides & $31.4-43.0$ & $9.4-12.1$ & $7.9-9.5$ & $6.3-7.8$ & $4.3-5.3$ & $5.9-7.4$ & $0.80-0.82$ & $0.53-0.54$ & $545-745$ & $1935-2484$ \\
\hline spring tides & $36.8-28.3$ & $9.7-12.5$ & $11.0-13.3$ & $7.9-9.8$ & $4.2-5.2$ & $6.7-8.5$ & $0.72-0.74$ & $0.38-0.39$ & $637-828$ & $1880-2419$ \\
\hline \multicolumn{11}{|c|}{ Conwy Estuary } \\
\hline neap tides & $157.5-175$ & $49.5-54.9$ & $89.9-98.7$ & $56.8-63.1$ & $31.8-35.3$ & $38.7-43.0$ & $0.63-0.64$ & $0.35-0.36$ & $9.5-10.4$ & $30.25-32.95$ \\
\hline spring tides & $100-111.2$ & $36.7-40.7$ & $120.7-134$ & $54.8-60.8$ & $28.1-31.2$ & $31.9-35.3$ & $0.45-0.46$ & $0.23-0.24$ & $14.9-16.3$ & $40.63-44.27$ \\
\hline \multicolumn{11}{|c|}{ Mersey Estuary } \\
\hline average conditions & $4.9-13.4$ & $1.9-7.6$ & $27.4-72.4$ & $4.2-11.3$ & $1.8-6.9$ & $1.8-7.2$ & $0.16-0.17$ & $0.07-0.10$ & $304-1070$ & $534-2771$ \\
\hline \multicolumn{11}{|c|}{ Scheldt Estuary } \\
\hline average conditions & $146-207$ & $9.7-26.8$ & $161-214.4$ & 76.4-105.4 & $9.2-23.8$ & $9.5-25.2$ & $0.47-0.49$ & $0.06-0.11$ & $581-826$ & 2996-9268 \\
\hline \multicolumn{11}{|c|}{ York River Estuary } \\
\hline high flow & $45.0-81.0$ & $17.7-36.0$ & 109.3-161.9 & $31.9-54.0$ & $15.2-29.9$ & $16.4-32.4$ & $0.28-0.33$ & $0.14-0.18$ & $316-568$ & $974-1053$ \\
\hline mean flow & $112.2-201.9$ & $44.2-89.8$ & $272.6-403.9$ & $79.5-134.6$ & $38.0-73.4$ & $40.9-80.8$ & $0.29-0.33$ & $0.14-0.18$ & $127-228$ & $390-422$ \\
\hline
\end{tabular}


Table 2 - The mean residence time ( $\bar{\phi}_{C A R T}$ in days), mean exposure time ( $\bar{\Theta}_{C A R T}$ in days), and the return coefficient of the Curimataú, Caravelas, Peruípe, Hudson, Conwy, Mersey, Scheldt and York estuaries. The Peclet number $P_{E}=u L / K$ was calculated using the coefficient $K$ from Fisher's formula (see Table 1), which was used in our method. $\bar{\phi}_{a}$ and $\bar{\Theta}_{a}$ correspond to the mean advective timescale in the residence time and exposure time, respectively.

\begin{tabular}{|c|c|c|c|c|c|c|c|c|}
\hline \multicolumn{9}{|c|}{ Curimataú Estuary } \\
\hline Conditions & $P_{E}$ & $\bar{\phi}_{a}$ and $\bar{\Theta}_{a}$ & $\bar{\phi}_{b}$ & $\bar{\Theta}_{b}$ & $\bar{\phi}_{C A R T}$ & $\bar{\Theta}_{C A R T}$ & Return coefficient & \begin{tabular}{|c|} 
Residence time \\
from Numerical Model
\end{tabular} \\
\hline neap tides & $1.02-3.27$ & $0.7-1.2$ & -0.6 & 0.5 & $0.1-0.6$ & $1.2-1.7$ & $0.65-0.92$ & - \\
\hline spring tides & $0.25-0.76$ & $2.2-3.6$ & -2.1 to -3.1 & $2.0-2.8$ & $0.1-0.5$ & $4.1-6.4$ & $0.92-0.98$ & - \\
\hline \multicolumn{9}{|c|}{ Caravelas Estuary } \\
\hline neap tides & $0.02-1.25$ & $27.8-194.5$ & -158.0 to -27.7 & $27.6-137.2$ & $0.1-36.3$ & $55.4-331.7$ & $0.89-0.99$ & \multirow{2}{*}{$4.2-10.3$} \\
\hline spring tides & $0.02-0.98$ & $27.8-194.5$ & -163.2 to -27.7 & $27.6-143.9$ & $0.1-21.3$ & $55.4-338.3$ & 0.89-0.99 & \\
\hline \multicolumn{9}{|c|}{ Peruípe Estuary } \\
\hline neap tides & $0.04-1.47$ & $1.7-7.0$ & -5.3 to -1.1 & $1.1-4.5$ & $0.1-1.6$ & $2.3-11.5$ & $0.86-0.96$ & \multirow{2}{*}{$1.5-2.5$} \\
\hline spring tides & $0.02-0.56$ & $1.7-7.0$ & -6.3 to -1.2 & $1.1-5.8$ & $0.1-0.7$ & $2.3-12.8$ & $0.86-0.95$ & \\
\hline \multicolumn{9}{|c|}{ Hudson Estuary } \\
\hline neap tides & $3.32-5.47$ & $4.0-4.8$ & -2.1 to -1.6 & $1.4-1.7$ & $1.9-3.1$ & $5.4-6.2$ & $0.50-0.65$ & $8-10$ \\
\hline spring tides & $2.13-3.34$ & $5.5-6.7$ & -3.5 to -3.7 & $2.9-3.0$ & $1.8-3.2$ & $8.5-9.6$ & $0.67-0.79$ & $8-9$ \\
\hline \multicolumn{9}{|c|}{ Conwy Estuary } \\
\hline neap tides & $1.62-1.93$ & $45.0-49.4$ & -34.4 to -33.3 & $28.0-28.5$ & $11.6-15.0$ & $73.0-77.9$ & $0.81-0.84$ & - \\
\hline spring tides & $0.76-0.91$ & $60.4-67.0$ & -57.0 to -52.8 & $47.6-50.6$ & $7.6-10.0$ & 107.9-117.6 & $0.92-0.93$ & - \\
\hline \multicolumn{9}{|c|}{ Mersey Estuary } \\
\hline Average conditions & $0.16-0.21$ & $13.7-36.2$ & -20.0 to -43.7 & $19.5-63.9$ & $0.6-1.6$ & $40.0-109.2$ & $0.98-0.99$ & $0.7-4$ \\
\hline \multicolumn{9}{|c|}{ Scheldt Estuary } \\
\hline Average conditions & $0.91-0.97$ & $80.5-107.2$ & -90.1 to -68.5 & $60.8-79.5$ & $12.0-17.1$ & $141.3-186.7$ & $0.91-0.92$ & $5-70$ \\
\hline \multicolumn{9}{|c|}{ York River Estuary } \\
\hline high flow & $0.28-0.74$ & $54.7-81.0$ & -52.1 to -71.1 & $49.9-64.2$ & $2.5-9.9$ & $104.5-145.1$ & $0.93-0.98$ & $11.3-33.3$ \\
\hline mean flow & $0.28-0.74$ & $136.4-201.9$ & -130 to -177.3 & $124.4-160.1$ & $6.3-24.7$ & $260.7-362.1$ & $0.93-0.98$ & $18.1-59.3$ \\
\hline
\end{tabular}




\section{Appendix 1}

Features of the Curimataú Estuary, Brazil (Miranda et al., 2005; Miranda et al., 2006; Andutta et al., 2006).

\begin{tabular}{|c|c|}
\hline Feature & Curumataú Estuary \\
\hline mean estuary depth $h(\mathrm{~m})$ & $6-7$ \\
\hline mean estuary width $l(\mathrm{~m})$ & $250-350$ \\
\hline mean estuary cross-sectional area $A\left(\mathrm{~m}^{2}\right)$ & $1500-2450$ \\
\hline longitudinal distance $L(\mathrm{~m})$ & 10000 \\
\hline estuary volume $V\left(\mathrm{~m}^{3}\right) \times 10^{6}$ & $15-24.5$ \\
\hline \multirow[t]{2}{*}{ river discharge $Q\left(\mathrm{~m}^{3} \mathrm{~s}^{-1}\right)$} & 120 (measured in neap tides) \\
\hline & 40 (measured in spring tides) \\
\hline \multirow[t]{2}{*}{ gradient of salinity $d S / L\left(\mathrm{psu} \mathrm{m}^{-1}\right)$} & neap tides $3.0 \times 10^{-3}$ \\
\hline & spring tides $1.3 \times 10^{-3}$ \\
\hline \multirow[t]{2}{*}{ estuarine salinity $S_{E}$} & $S_{E \text { (neap) }} 15-18$ \\
\hline & $S_{E(\text { spring })} 28-32$ \\
\hline \multirow[t]{2}{*}{ salinity at mouth $S_{O}$} & $S_{O(\text { neap })} 30$ \\
\hline & $S_{O(\text { spring })} 36$ \\
\hline \multirow{2}{*}{ salinity at $10 \mathrm{~km}$ away from the mouth; $S^{\prime}$} & $S_{U P \text { (neap) }} 0$ \\
\hline & $S_{U P \text { (spring) }} 23$ \\
\hline \multirow{2}{*}{$\begin{array}{c}\text { dispersion } K\left(\mathrm{~m}^{2} \mathrm{~s}^{-1}\right) \\
\text { Hansen-Rattray's formula }\end{array}$} & $K_{(\text {neap) }} 250-800$ \\
\hline & $K_{(\text {spring })} 435-1400$ \\
\hline \multirow{2}{*}{$\begin{array}{l}\text { dispersion } K\left(\mathrm{~m}^{2} \mathrm{~s}^{-1}\right) \\
\text { Fisher's formula }\end{array}$} & $K_{(\text {neap })} 490-960$ \\
\hline & $K_{(\text {spring) }} 703-1313$ \\
\hline
\end{tabular}

Estimative of horizontal dispersion $K$ to the Curimataú Estuary using Hansen-Rattray formula and vertical steady state salinity profiles of Miranda et al., 2005

\begin{tabular}{|c|c|c|c|c|}
\hline Parameters & & ide & \multicolumn{2}{|c|}{ Spring tide } \\
\hline residual velocity- $u\left(\mathrm{~m} \mathrm{~s}^{-1}\right)$ & \multicolumn{2}{|c|}{0.057} & \multicolumn{2}{|c|}{0.016} \\
\hline salinity at $(x=10 \mathrm{~km})-S_{U P}$ & & & \multicolumn{2}{|c|}{23} \\
\hline salinity at mouth $-S_{O}$ & \multicolumn{2}{|c|}{30} & \multicolumn{2}{|c|}{36} \\
\hline longitudinal distance $-L(\mathrm{~m})$ & \multicolumn{2}{|c|}{10000} & \multicolumn{2}{|c|}{10000} \\
\hline position of the vertical profile $\mathrm{x}(\mathrm{m})$ & \multicolumn{2}{|c|}{5000} & \multicolumn{2}{|c|}{5000} \\
\hline non-dimensional number $(v)$ & \multicolumn{2}{|c|}{0.65} & \multicolumn{2}{|c|}{1} \\
\hline vertical viscosity $-N_{z}\left(\mathrm{~m}^{2} \mathrm{~s}^{-1}\right)$ & \multicolumn{2}{|c|}{$1 \times 10^{-4}$} & \multicolumn{2}{|c|}{$5 \times 10^{-4}$} \\
\hline vertical difusivity $-K_{z}\left(\mathrm{~m}^{2} \mathrm{~s}^{-1}\right)$ & \multicolumn{2}{|c|}{$1 \times 10^{-3}$} & \multicolumn{2}{|c|}{$1 \times 10^{-3}$} \\
\hline wind strees $-\left(\mathrm{Nm}^{-2}\right)$ & \multicolumn{2}{|c|}{0} & \multicolumn{2}{|c|}{0} \\
\hline average depth $-h(\mathrm{~m})$ & 6 & 7 & 6 & 7 \\
\hline estuarine salinity $-S_{E}$ & $17.0-19$ & $20.3-23.5$ & $29.0-30.0$ & $30.3-32.5$ \\
\hline
\end{tabular}




\section{Appendix 2}

Features of the Caravelas Estuary, Brazil (Schettini and Miranda 2010; Andutta, 2011).

\begin{tabular}{|c|c|}
\hline Feature & Caravelas Estuary \\
\hline mean estuary depth $h(\mathrm{~m})$ & $6-7$ \\
\hline mean estuary width $l(\mathrm{~m})$ & $600-800$ \\
\hline mean estuary cross-sectional area $A\left(\mathrm{~m}^{2}\right)$ & $3.6-5.6 \times 10^{3}$ \\
\hline longitudinal distance $L(\mathrm{~m})$ & $\sim 12000$ \\
\hline estuary volume $V\left(\mathrm{~m}^{3}\right) \times 10^{6}$ & $43.2-67.2$ \\
\hline river discharge $Q\left(\mathrm{~m}^{3} \mathrm{~s}^{-1}\right)$ & $Q \sim 2-9$ \\
\hline \multirow[t]{2}{*}{ gradient of salinity $d S / L\left(\mathrm{psu} \mathrm{m}^{-1}\right)$} & neap tides $4.75 \times 10^{-4}$ \\
\hline & spring tides $3.75 \times 10^{-4}$ \\
\hline \multirow[t]{2}{*}{ estuarine salinity $S_{E}$} & $S_{E(\text { neap })} 32-34$ \\
\hline & $S_{E(\text { spring })} 33-34$ \\
\hline \multirow[t]{2}{*}{ salinity at mouth $S_{O}$} & $S_{O(\text { neap })} 35.9$ \\
\hline & $S_{O(\text { spring })} 36.0$ \\
\hline \multirow[t]{2}{*}{ salinity at $10 \mathrm{~km}$ away from the mouth; $S_{U P}$} & $S_{U P \text { (neap) }} 30.2$ \\
\hline & $S_{U P \text { (spring) }} 31.5$ \\
\hline
\end{tabular}




\section{Appendix 3}

Features of the Peruípe Estuary, Brazil (Schettini and Miranda 2010; Andutta, 2011).

\begin{tabular}{|c|c|}
\hline Feature & Peruípe Estuary \\
\hline mean estuary depth $h(\mathrm{~m})$ & $7-8$ \\
\hline mean estuary width $l(\mathrm{~m})$ & $400-600$ \\
\hline mean estuary cross-sectional area $A\left(\mathrm{~m}^{2}\right)$ & $2.8-4.8 \times 10^{3}$ \\
\hline longitudinal distance $L(\mathrm{~m})$ & $\sim 5000$ \\
\hline estuary volume $V\left(\mathrm{~m}^{3}\right) \times 10^{6}$ & $14-24$ \\
\hline river discharge $Q\left(\mathrm{~m}^{3} \mathrm{~s}^{-1}\right)$ & $\mathrm{Q} \sim 20-70$ \\
\hline gradient of salinity $d S / L\left(\mathrm{psu} \mathrm{m}^{-1}\right)$ & neap tides $1.6 \times 10^{-3}$ \\
\cline { 2 - 2 } & $\mathrm{spring}$ tides $3.6 \times 10^{-4}$ \\
\hline estuarine salinity $S_{E}$ & $S_{E(\text { neap })} 26-28$ \\
\cline { 2 - 2 } & $S_{E(\text { spring })} 29-30$ \\
\hline salinity at mouth $S_{O}$ & $S_{O(\text { neap })} 31.6$ \\
\hline & $S_{O(\text { spring })} 32.0$ \\
\hline & $S_{U P(\text { neap })} 23.4$ \\
\hline salinity at 10 km away from the mouth; $S_{U P}$ & $S_{U P} 28.5$ \\
\hline
\end{tabular}




\section{Appendix 4}

Features of the Hudson Estuary, USA (Warner et al., 2005).

\begin{tabular}{|c|c|}
\hline Feature & Hudson Estuary \\
\hline mean estuary depth $h(\mathrm{~m})$ & $7.5-8.5$ \\
\hline mean estuary width $l(\mathrm{~m}) \times 10^{3}$ & $1.55-1.65$ \\
\hline mean estuary cross-sectional area $A\left(\mathrm{~m}^{2}\right) \times 10^{3}$ & $11.625-14.025$ \\
\hline longitudinal distance $L(\mathrm{~m})$ & 45000 \\
\hline estuary volume $V\left(\mathrm{~m}^{3}\right) \times 10^{6}$ & $523-631$ \\
\hline river discharge $Q\left(\mathrm{~m}^{3} \mathrm{~s}^{-1}\right)$ & 770 (measured in neap tides) \\
\hline & 550 (measured in spring tides) \\
\hline gradient of salinity $d S / L\left(\mathrm{psu} \mathrm{m}^{-1}\right)$ & neap tides $4.7 \times 10^{-4}$ \\
\cline { 2 - 2 } & spring tides $4.9 \times 10^{-4}$ \\
\hline estuarine salinity $S_{E}$ & $S_{E(\text { neap })} 7.5-8.5$ \\
\cline { 2 - 2 } & $S_{E(\text { spring })} 13-14$ \\
\hline salinity at mouth $S_{O}$ & $S_{O(\text { neap })} 34$ \\
\cline { 2 - 2 } & $S_{O(\text { spring })} 36$ \\
\hline salinity at 45 km away from the mouth; $S_{U P}$ & $S_{U P(\text { neap })} 0$ \\
\cline { 2 - 2 } & $S_{U P(\text { spring })} 0$ \\
\hline
\end{tabular}




\section{Appendix 5}

Features of the Conwy Estuary, UK (Turrell et al., 1996).

\begin{tabular}{|c|c|c|c|c|c|c|}
\hline \multicolumn{7}{|c|}{ Geometry features by segments } \\
\hline segment & $\begin{array}{l}\text { distance from } \\
\text { Deganwy } \\
\text { Narrows }(\mathrm{km})\end{array}$ & $\begin{array}{l}\text { length } \\
L(\mathrm{~km})\end{array}$ & $\begin{array}{l}\text { width } \\
l(\mathrm{~m})\end{array}$ & $\begin{array}{l}\text { depth } \\
h(\mathrm{~m})\end{array}$ & $\begin{array}{c}\text { area } \\
\times 10^{3} A\left(\mathrm{~m}^{2}\right)\end{array}$ & $\begin{array}{c}\text { volume } \\
\mathrm{x} 10^{6} V\left(\mathrm{~m}^{3}\right)\end{array}$ \\
\hline a) & $2.44-3.93$ & 1.5 & 530 & $5.0-5.5$ & $2.7-2.9$ & $V_{a}=4.0-4.3$ \\
\hline b) & $3.93-7.86$ & 3.9 & 430 & $4.5-5.0$ & $1.9-2.2$ & $V_{b}=7.6-8.4$ \\
\hline c) & $7.86-9.51$ & 1.7 & 225 & $4.0-4.5$ & $900-1013$ & $V_{c}=1.5-1.7$ \\
\hline d) & $9.51-11.14$ & 1.6 & 120 & $3.5-4.0$ & $420-480$ & $V_{d}=0.7-0.8$ \\
\hline e) & $11.14-14.32$ & 3.2 & 90 & $3.0-3.5$ & $270-315$ & $V_{e}=0.9-1.0$ \\
\hline total & $2.44-14.32$ & 11.9 & $246-274$ & 5.0 & $1228-1368$ & $V_{\text {total }}=14.6-16.2$ \\
\hline \multicolumn{7}{|c|}{ Features of salinity by segments } \\
\hline segment & $\begin{array}{c}\text { Volume } \\
\text { normalized }\end{array}$ & \multicolumn{2}{|c|}{$\Delta S$ (neap) } & So (neap) & $\Delta S$ (spring) & So (spring) \\
\hline a) & $V_{e} / V_{\text {total }} \sim 0.27$ & \multicolumn{2}{|c|}{$26.5-28.0$} & $S_{a} \sim 27.3$ & $30.0-32.0$ & $S_{a} \sim 31.0$ \\
\hline b) & $V_{b} / V_{\text {total }} \sim 0.52$ & \multirow{2}{*}{\multicolumn{2}{|c|}{$\frac{15.0-26.5}{10.5-15.0}$}} & $S_{b} \sim 20.8$ & $24.2-30.0$ & $S_{b} \sim 27.1$ \\
\hline c) & $V_{d} / V_{\text {total }} \sim 0.10$ & & & $S_{c} \sim 12.8$ & $20.5-24.2$ & $S_{c} \sim 22.4$ \\
\hline d) & $V_{d} / V_{\text {total }} \sim 0.05$ & \multicolumn{2}{|c|}{$5.0-10.5$} & $S_{d} \sim 7.8$ & $19.0-20.5$ & $S_{d} \sim 19.8$ \\
\hline e) & $V_{e} / V_{\text {total }} \sim 0.06$ & \multicolumn{2}{|c|}{$0.0-5.0$} & $S_{e} \sim 2.5$ & $13.9-19.0$ & $S_{e} \sim 16.5$ \\
\hline total & $V_{\text {total }} / V_{\text {total }}=1$ & \multicolumn{2}{|c|}{$0.0-28.0$} & $S_{\text {total }} \sim 20.0$ & $13.9-32.0$ & $S_{\text {total }} \sim 26.7$ \\
\hline \multicolumn{7}{|c|}{$\begin{array}{l}\text { Notes: To estimate each segment mean width it was used the ruler tool from Google Earth. The mean salinity } \\
\text { of the entire system was calculated from the volume normalizer expression: } \\
S_{\text {total }}=S_{a} \cdot \frac{V_{a}}{V_{\text {total }}}+S_{b} \cdot \frac{V_{b}}{V_{\text {total }}}+\ldots+S_{f} \cdot \frac{V_{f}}{V_{\text {total }}}\end{array}$} \\
\hline
\end{tabular}

\begin{tabular}{|c|c|}
\hline Feature & Conwy Estuary \\
\hline mean estuary depth $h(\mathrm{~m})$ & 5.0 \\
\hline mean estuary width $l(\mathrm{~m})$ & $246-274$ \\
\hline $\begin{array}{l}\text { mean estuary cross-sectional area } A \\
\left(\mathrm{~m}^{2}\right) \times 10^{3}\end{array}$ & $1.23-1.34$ \\
\hline longitudinal distance $L(\mathrm{~m})$ & 11880 \\
\hline estuary volume $V\left(\mathrm{~m}^{3}\right) \times 10^{6}$ & $14.6-16.2$ \\
\hline \multirow[t]{2}{*}{ river discharge $Q\left(\mathrm{~m}^{3} \mathrm{~s}^{-1}\right)$} & 1.9 (measured in neap tides) \\
\hline & 1.4 (measured in spring tides) \\
\hline \multirow[t]{2}{*}{ gradient of salinity $d S / L\left(\mathrm{psu} \mathrm{m}^{-1}\right)$} & neap tides $2.4 \times 10^{-3}$ \\
\hline & spring tides $1.5 \times 10^{-3}$ \\
\hline \multirow[t]{2}{*}{ estuarine salinity $S_{E}$} & $S_{(\text {neap })} 19.19$ \\
\hline & $S_{\text {(spring) }} 26.46$ \\
\hline \multirow[t]{2}{*}{ salinity at mouth $S_{O}$} & $S_{O(\text { neap })} 34$ \\
\hline & $S_{O(\text { spring })} 36$ \\
\hline \multirow{2}{*}{$\begin{array}{c}\text { salinity at } 11.88 \mathrm{~km} \text { away from the } \\
\text { mouth; } S_{U P}\end{array}$} & $S_{U P(\text { neap })} 0$ \\
\hline & $S_{U P(\text { spring })} 14$ \\
\hline
\end{tabular}




\section{Appendix 6}

Features of the Mersey Estuary, UK (Bowden and Gilligan, 1971; Wu et al., 2005; Yuan et al., 2007).

\begin{tabular}{|c|c|c|c|c|c|c|}
\hline \multicolumn{7}{|c|}{ Geometry features by segments } \\
\hline Segment & $\begin{array}{l}\text { Distance from Mersey } \\
\text { entrance }(\mathrm{km})\end{array}$ & $\begin{array}{l}\text { Length } \\
L(\mathrm{~km})\end{array}$ & $\begin{array}{l}\text { Width } \\
l(\mathrm{~m})\end{array}$ & $\begin{array}{l}\text { Depth } \\
h(\mathrm{~m})\end{array}$ & $\begin{array}{c}\text { Area } \\
\times 10^{3} \mathrm{~A} \\
\left(\mathrm{~m}^{2}\right)\end{array}$ & $\begin{array}{c}\text { Volume } \\
V \times 10^{6}\left(\mathrm{~m}^{3}\right)\end{array}$ \\
\hline a) & $0-4.4 .4$ & 4.4 & 1200 & $15-17$ & $18.7-21.2$ & $V_{a} 233-264$ \\
\hline b) & $4.41-7.86$ & 3.7 & 1200 & $15-17$ & $17.9-20.3$ & $V_{b} 214-243$ \\
\hline c) & $7.86-12.83$ & 5 & 2400 & $15-17$ & $35.7-40.5$ & $V_{c} 850-963$ \\
\hline d) & $12.83-20$ & 7.2 & 3500 & $15-17$ & $52.5-59.5$ & $V_{d} 184-208$ \\
\hline total & $0-20$ & 20 & 1400 & $15-17$ & $15.7-17.7$ & $V_{\text {total }} 313-355$ \\
\hline \multicolumn{7}{|c|}{ Features of salinity by segments } \\
\hline Segment & \multicolumn{2}{|c|}{ Volume normalized } & \multicolumn{2}{|c|}{$\Delta S$} & \multicolumn{2}{|c|}{ So } \\
\hline a) & \multicolumn{2}{|c|}{$V_{d} / V_{\text {total }} \sim 0.07$} & \multicolumn{2}{|c|}{$29.4-30.1$} & \multicolumn{2}{|c|}{$S_{a} \sim 29.75$} \\
\hline b) & \multicolumn{2}{|c|}{$V_{b} / V_{\text {total }} \sim 0.07$} & \multicolumn{2}{|c|}{$28.7-29.4$} & \multicolumn{2}{|c|}{$S_{b} \sim 29.05$} \\
\hline c) & \multicolumn{2}{|c|}{$V_{d} / V_{\text {total }} \sim 0.27$} & \multicolumn{2}{|c|}{$27.8-28.7$} & \multicolumn{2}{|c|}{$S_{c} \sim 28.25$} \\
\hline d) & \multirow{2}{*}{\multicolumn{2}{|c|}{$V_{d} / V_{\text {total }} \sim 0.59$}} & \multirow{2}{*}{\multicolumn{2}{|c|}{$\begin{array}{l}24.9-27.8 \\
24.9-30.1\end{array}$}} & \multicolumn{2}{|c|}{$\begin{array}{l}S_{d} \sim 26.35 \\
\end{array}$} \\
\hline total & $V_{\text {total }} / V_{\text {total }}=1$ & & & & \multicolumn{2}{|c|}{$S_{\text {total }} \sim 27.29$} \\
\hline \multicolumn{7}{|c|}{$\begin{array}{l}\text { Notes: To estimate each segment mean width it was used the ruler tool from Google Earth. The mean salinity of } \\
\text { the entire system was calculated from the volume normalizer expression: }\end{array}$} \\
\hline$S-S \quad V_{a}+S \quad V_{b}+S \quad V_{f}$ & \multicolumn{6}{|c|}{$S_{\text {total }}=S_{a} \cdot \frac{a}{V_{\text {total }}}+S_{b} \cdot \frac{o}{V_{\text {total }}}+\ldots+S_{f} \cdot \overline{V_{\text {total }}}$} \\
\hline
\end{tabular}

\begin{tabular}{|c|c|}
\hline Feature & Mersey Estuary \\
\hline mean estuary depth $h(\mathrm{~m})$ & $15-17$ \\
\hline mean estuary width $l(\mathrm{~m})$ & 1445 \\
\hline $\begin{array}{c}\text { mean estuary cross-sectional } \\
\text { area } A\left(\mathrm{~m}^{2}\right) \times 10^{3}\end{array}$ & $15.7-17.8$ \\
\hline longitudinal distance $L(\mathrm{~m})$ & 20000 \\
\hline estuary volume $V\left(\mathrm{~m}^{3}\right) \times 10^{6}$ & $313-355$ \\
\hline river discharge $Q\left(\mathrm{~m}^{3} \mathrm{~s}^{-1}\right)$ & $50-150($ range $)$ \\
\hline $\begin{array}{c}\text { gradient of salinity } d S / d x \\
\left(\mathrm{psu} \mathrm{m}^{-1}\right)\end{array}$ & $2.6 \times 10^{-4}$ \\
\hline estuarine salinity $S_{E}$ & $27-28$ \\
\hline salinity at mouth $S_{O}$ & 30 \\
\hline $\begin{array}{c}\text { salinity at } 20 \mathrm{~km} \text { upstream } \\
\text { from the mouth; } S_{U P}\end{array}$ & 25 \\
\hline
\end{tabular}




\section{Appendix 7}

Features of the Scheldt Estuary, (de Brauwere et al., 2011; de Brye et al., 2012).

\begin{tabular}{|c|c|c|c|c|c|}
\hline \multicolumn{7}{|c|}{ Geometry features by segments } \\
\hline Segment & $\begin{array}{c}\text { Length } \\
L(\mathrm{~km})\end{array}$ & $\begin{array}{c}\text { Width } \\
l(\mathrm{~m})\end{array}$ & $\begin{array}{c}\text { Depth } \\
h(\mathrm{~m})\end{array}$ & $\begin{array}{c}\text { Cross-sectional Area } \\
\mathrm{A} 10^{3}\left(\mathrm{~m}^{2}\right)\end{array}$ & $\begin{array}{c}\text { Volume } \\
V 10^{3}\left(\mathrm{~m}^{3}\right)\end{array}$ \\
\hline 1 & 7950 & 372.5 & 9.0 & 3.35 & $\mathrm{~V}_{1}=26649$ \\
\hline 2 & 8300 & 370.2 & 10.4 & 3.85 & $\mathrm{~V}_{2}=31957$ \\
\hline 3 & 9600 & 666.0 & 9.3 & 6.19 & $\mathrm{~V}_{3}=59460$ \\
\hline 4 & 5100 & 559.3 & 10.1 & 5.65 & $\mathrm{~V}_{4}=28807$ \\
\hline 5 & 9700 & 779.9 & 9.0 & 7.02 & $\mathrm{~V}_{5}=69830$ \\
\hline 6 & 5950 & 2754.8 & 8.0 & 22.04 & $\mathrm{~V}_{6}=131128$ \\
\hline 7 & 5700 & 2533.2 & 6.0 & 15.20 & $\mathrm{~V}_{7}=86636$ \\
\hline 8 & 5300 & 2702.9 & 7.4 & 20.00 & $\mathrm{~V}_{8}=106008$ \\
\hline 9 & 5900 & 2257.2 & 11.9 & 26.86 & $\mathrm{~V}_{9}=158476$ \\
\hline 10 & 6900 & 5033.6 & 9.0 & 45.30 & $\mathrm{~V}_{10}=312588$ \\
\hline 11 & 6200 & 4889.5 & 9.9 & 48.41 & $\mathrm{~V}_{11}=300120$ \\
\hline 12 & 12100 & 4088.7 & 12.0 & 49.06 & $\mathrm{~V}_{12}=593684$ \\
\hline 13 & 13300 & 4791.6 & 13.7 & 65.65 & $\mathrm{~V}_{13}=873080$ \\
\hline Total & 102000 & 2808.2 & 9.7 & 27.24 & 2778423 \\
\hline
\end{tabular}

\begin{tabular}{|c|c|}
\hline Feature & Scheldt Estuary \\
\hline mean estuary depth $h(\mathrm{~m})$ & 9.7 \\
\hline mean estuary width $l(\mathrm{~m})$ & 2808.2 \\
\hline mean estuary cross-sectional area $A\left(\mathrm{~m}^{2}\right) \times 10^{3}$ & 27.24 \\
\hline longitudinal distance $L(\mathrm{~m})$ & 102000 \\
\hline estuary volume $V\left(\mathrm{~m}^{3}\right) \times 10^{6}$ & 2778 \\
\hline river discharge $Q\left(\mathrm{~m}^{3} \mathrm{~s}^{-1}\right)$ & $150-200($ average range) \\
\hline gradient of salinity $d S / L\left(\mathrm{psu} \mathrm{m}^{-1}\right)$ & $1.0 \times 10^{-4}$ \\
\hline estuarine salinity $S_{E}$ & $30-32$ \\
\hline salinity at mouth $S_{O}$ & 34 \\
\hline salinity at 102 km away from the mouth; $S_{U P}$ & 5 \\
\hline
\end{tabular}




\section{Appendix 8}

Features of the York River Estuary, (Sandifer, 1973; Hass, 1977; Shen and Haas, 2004).

\begin{tabular}{|c|c|}
\hline Feature & York River Estuary \\
\hline mean estuary depth $h(\mathrm{~m})$ & $8-10$ \\
\hline mean estuary width $l(\mathrm{~m})$ & $2700-3200$ \\
\hline mean estuary cross-sectional area $A\left(\mathrm{~m}^{2}\right) \times 10^{3}$ & $21.6-32.0$ \\
\hline longitudinal distance $L(\mathrm{~m})$ & 47000 \\
\hline estuary volume $V\left(\mathrm{~m}^{3}\right) \times 10^{6}$ & $1015-1504$ \\
\hline river discharge (Mattaponi and Pamunkey rivers) $Q\left(\mathrm{~m}^{3} \mathrm{~s}^{-1}\right)$ & 43.1 (average) \\
\hline river discharge (Mattaponi and Pamunkey rivers) $Q\left(\mathrm{~m}^{3} \mathrm{~s}^{-1}\right)$ & 107.5 (high) \\
\hline estuarine salinity $S_{E}$ & $16-17$ \\
\hline salinity at mouth $S_{O}$ & 20 \\
\hline salinity at 47 km away from the mouth; $S_{U P}$ & $12-13$ \\
\hline
\end{tabular}




\section{FIGURE 1}

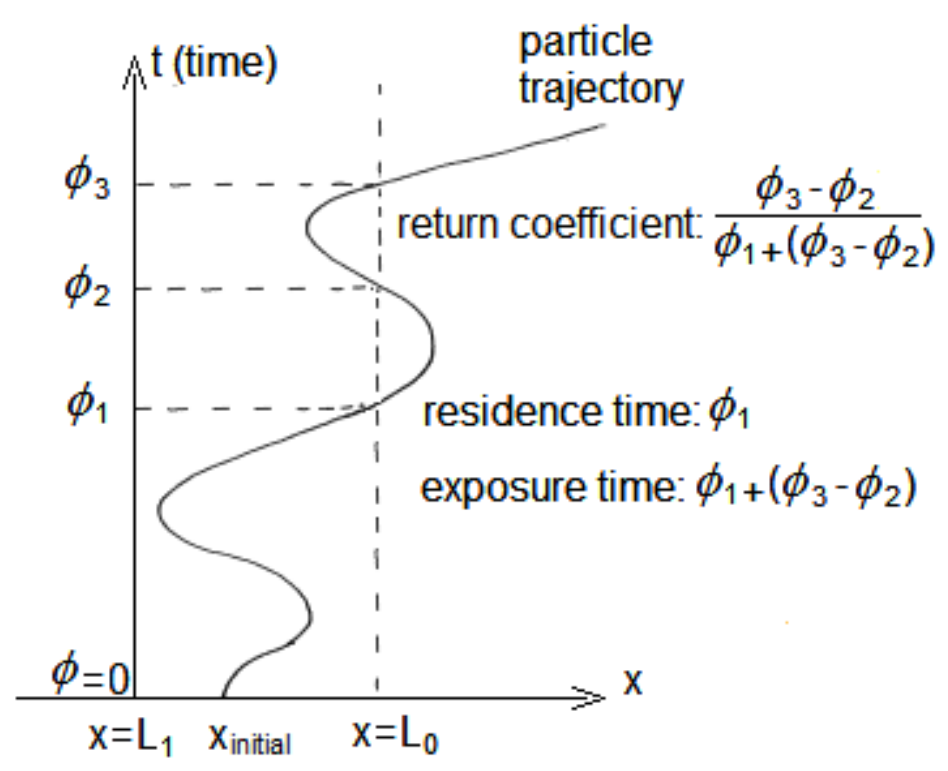

Figure 1- Illustration of the concept of residence and exposure times for a single water particle in the domain, between the upstream, $x=L_{1}$, and downstream, $x=L_{0}$, open boundaries. Residence time and exposure time are $\bar{\phi}=t_{1}$ and $\bar{\Theta}=t_{1}+\left(t_{3}-t_{2}\right)$, respectively. Timescales regarding a single particle are introduced for pedagogical purposes only, and are actually physically meaningless. 
FIGURE 2

(a)

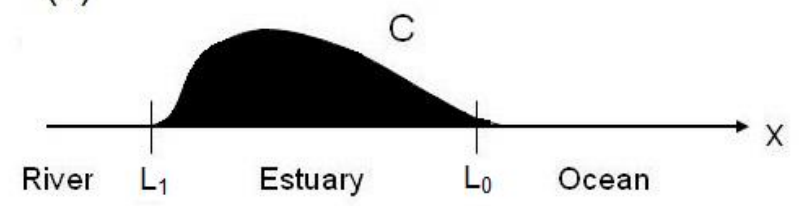

(c)

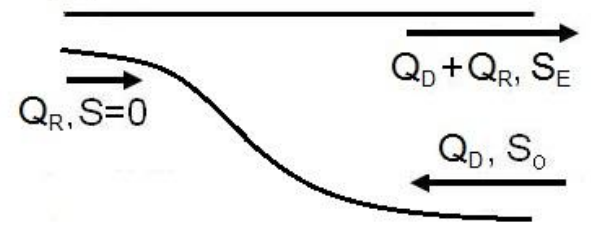

(b)

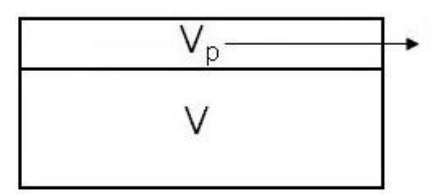

(d)

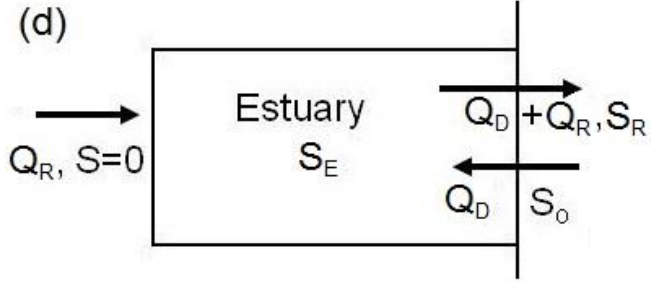

Figure 2 - (a) A 1-D estuary model; (b) the tidal prism box model (side view); (c) the gravitational circulation box model (side view); (d) the LOICZ box model for a vertically well-mixed estuary (plan view). 


\section{FIGURE 3}

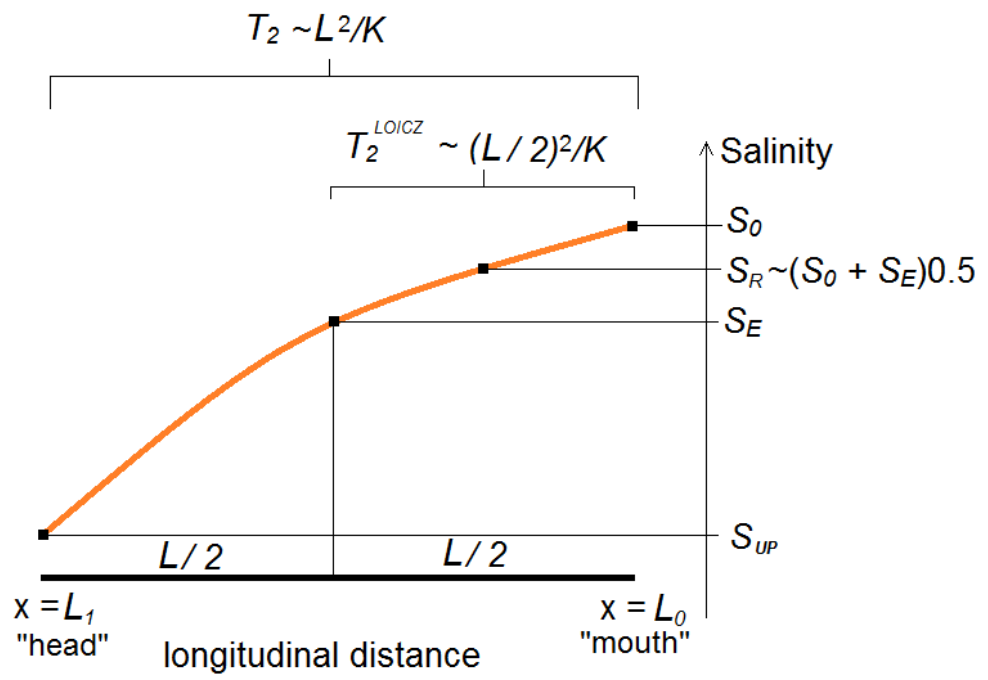

Figure 3 - Conceptual description of a generic salinity distribution along an estuary from $\left(x=L_{1}\right)$ to the mouth $\left(x=L_{0}\right)$. The salinity $S_{U P}$ at $x=L_{1}$, and $\left(0 \leq S_{U P}<S_{E}\right)$. 


\section{FIGURE 4}
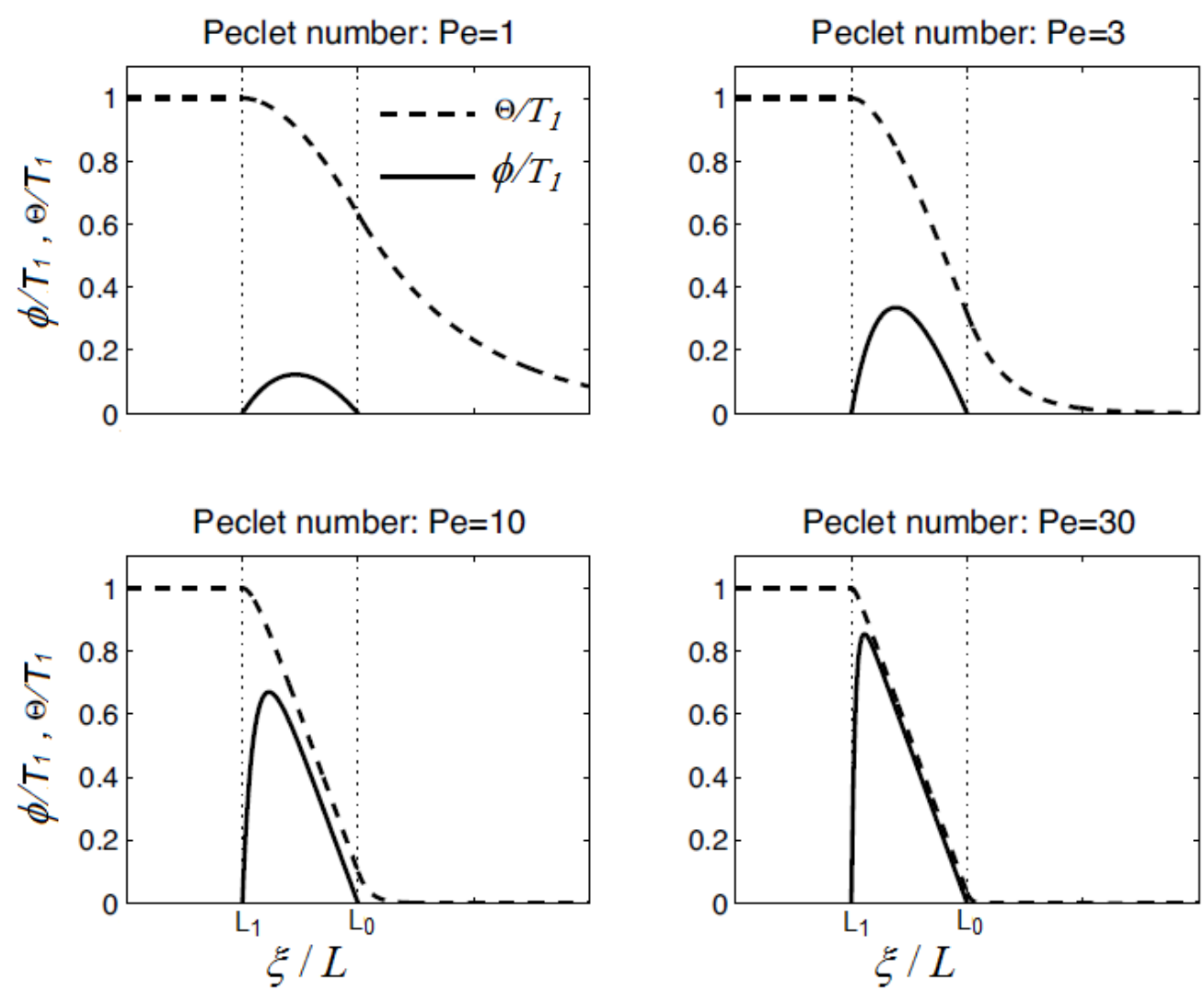

Figure 4 - Representation of the residence time $\phi$ (solid curve) and the exposure time $\Theta$ (dashed curve) as a function of the distance $x$ to the upstream boundary of the domain. The timescales are normalised by means of the advective timescale $T_{1}$. It is noteworthy that the exposure time, as opposed to the residence time, is defined including areas outside the domain of interest $\left(L_{1} \leq / L\right.$ $\left.\leq L_{0}\right)$. 


\section{FIGURE 5}

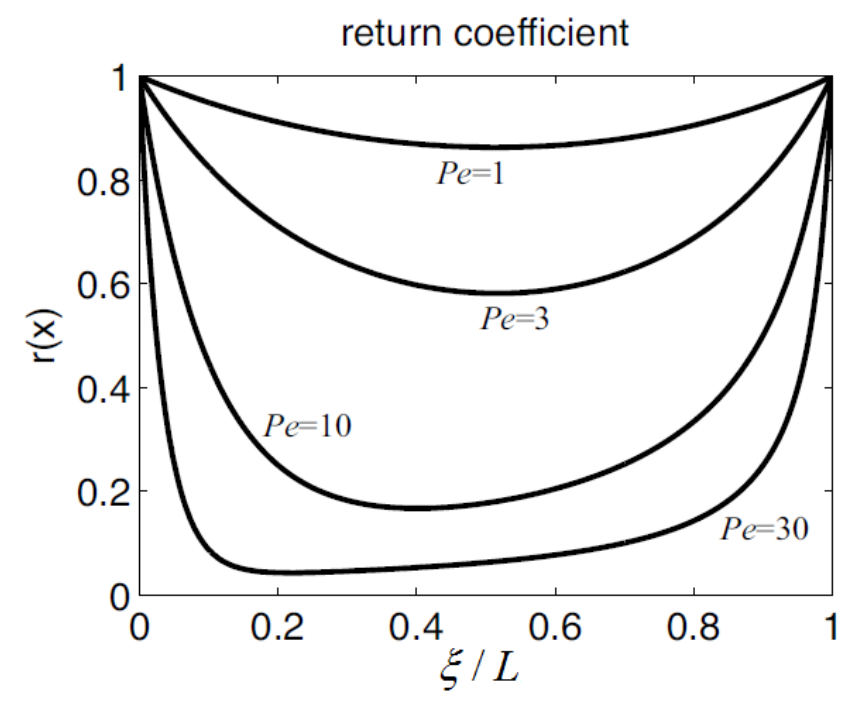

Figure 5 - Representation for various values of the Peclet number of the return coefficient as defined by formula (34). 
(a)

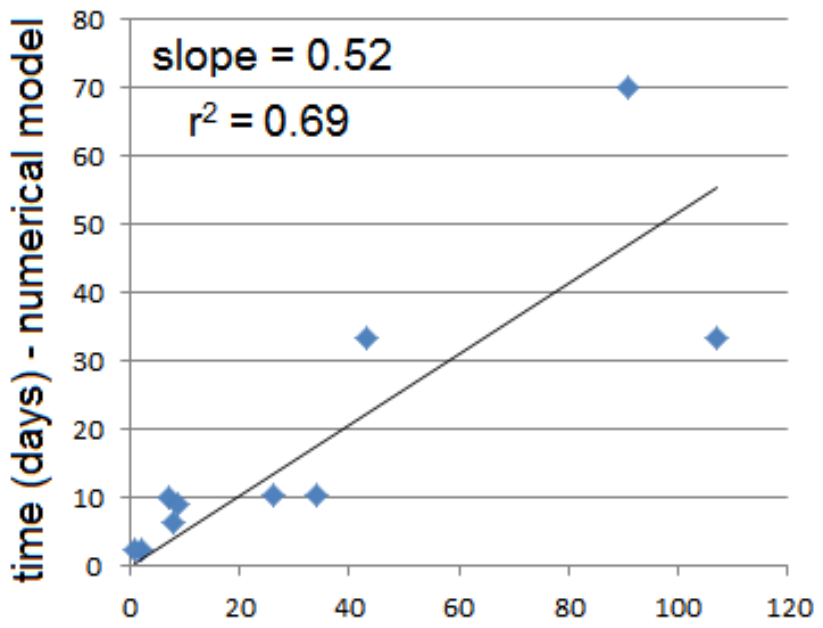

time (days) - modified LOICZ model - TP (b)

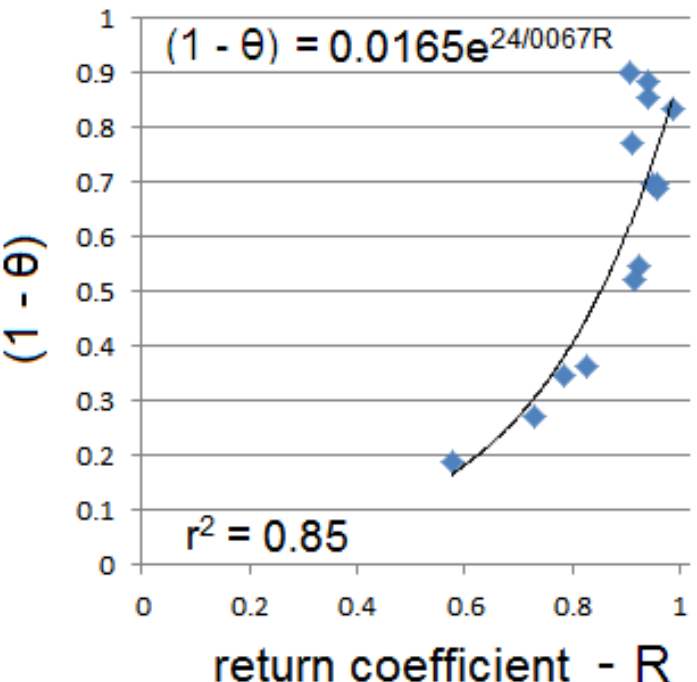

Figure 6 - (a) Scatter plot of the mean water renewal timescale, $T_{P}$, against the residence time at the upstream location from numerical models. (b) Scatter plot of the mean dispersive contribution to water renewal $(1-\theta)$ against the mean return coefficient calculated using CART's formula. 


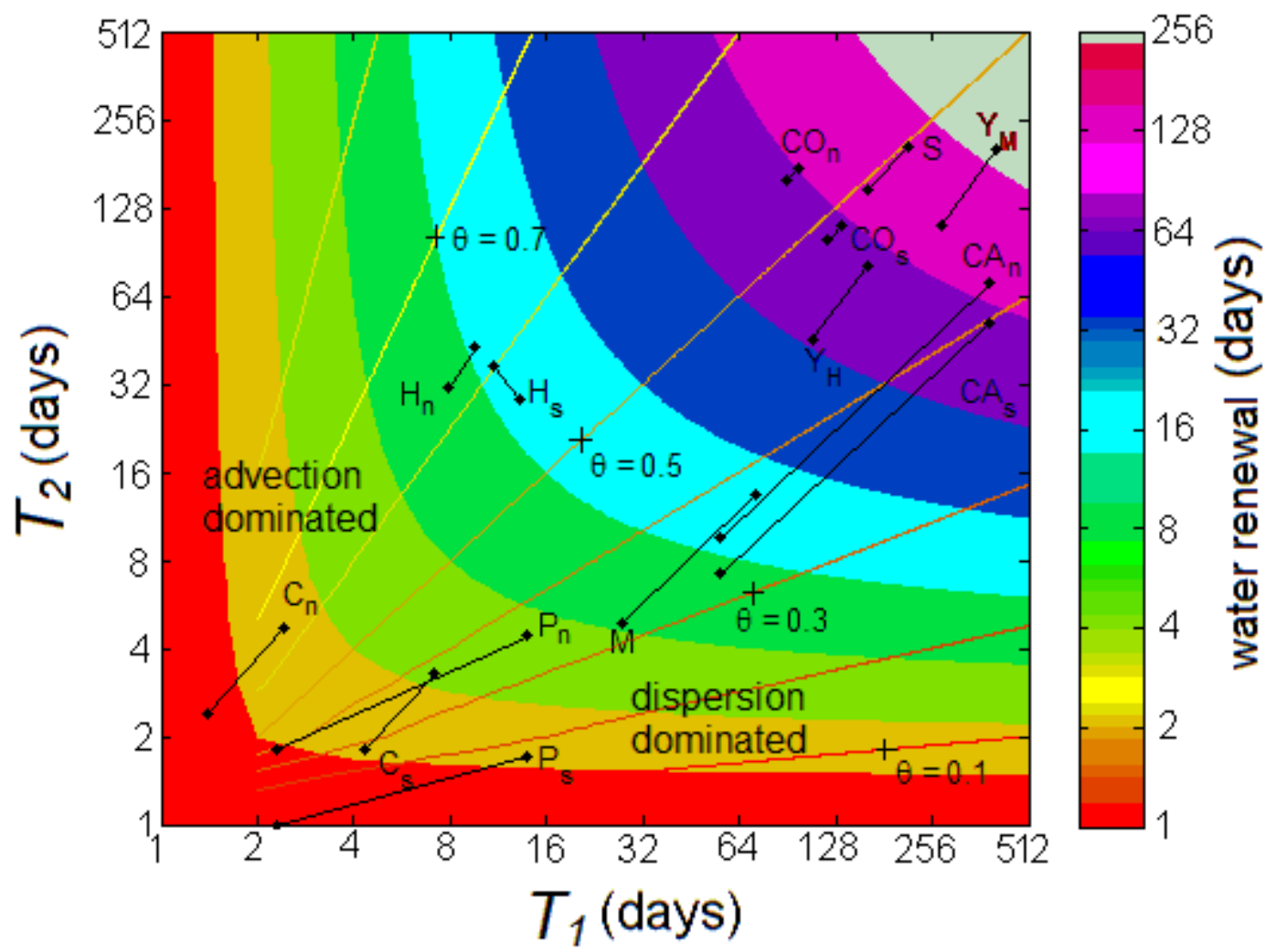

Figure 7- The position of estuaries on the advection-diffusion diagram to indicate the relative contribution to the water renewal $T_{P}$ by the advective $\left(T_{1}\right)$ and dispersive $\left(T_{2}\right)$ timescales using a logarithmic scale. Subscript (n) and (s) indicate neap and spring tide conditions. For the Curimataú Estuary (C), $K$ was estimated from Hansen-Rattray's formula. Hudson, Caravelas, Peruípe, and Conwy estuaries are denoted (H), (CA), (P), and (C), respectively. For the Mersey (M), and Scheldt (S) estuaries, results are from an average range. For the York River Estuary the conditions are for high river flow $\left(\mathrm{Y}_{\mathrm{H}}\right)$, and mean river flow $\left(\mathrm{Y}_{\mathrm{M}}\right)$. 